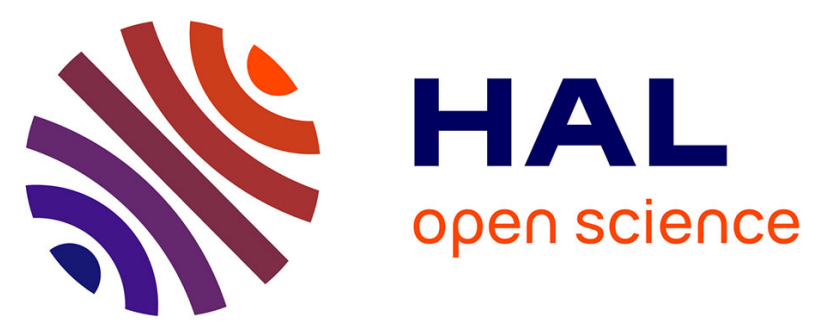

\title{
Synthesis, Cytotoxicity, and COMPARE Analysis of Ferrocene and [3] Ferrocenophane Tetrasubstituted Olefin Derivatives against Human Cancer Cells
}

Meral Goermen, Pascal Pigeon, Siden Top, Elisabeth A. Hillard, Michel Huché, Christian G. Hartinger, Frédéric De Montigny, Marie-Aude Plamont, Anne Vessières, Gérard Jaouen

\section{To cite this version:}

Meral Goermen, Pascal Pigeon, Siden Top, Elisabeth A. Hillard, Michel Huché, et al.. Synthesis, Cytotoxicity, and COMPARE Analysis of Ferrocene and [3]Ferrocenophane Tetrasubstituted Olefin Derivatives against Human Cancer Cells. ChemMedChem, 2010, 5 (12), pp.2039-2050. 10.1002/cmdc.201000286 . hal-01230394

\section{HAL Id: hal-01230394 https://hal.science/hal-01230394}

Submitted on 19 Jul 2018

HAL is a multi-disciplinary open access archive for the deposit and dissemination of scientific research documents, whether they are published or not. The documents may come from teaching and research institutions in France or abroad, or from public or private research centers.
L'archive ouverte pluridisciplinaire HAL, est destinée au dépôt et à la diffusion de documents scientifiques de niveau recherche, publiés ou non, émanant des établissements d'enseignement et de recherche français ou étrangers, des laboratoires publics ou privés. 


\title{
Synthesis, Cytotoxicity, and COMPARE Analysis of Ferrocene and [3]Ferrocenophane Tetrasubstituted Olefin Derivatives against Human Cancer Cells
}

\author{
Meral Görmen, ${ }^{[\mathrm{a}]}$ Pascal Pigeon, ${ }^{[\mathrm{a}]}$ Siden Top, ${ }^{*[\mathrm{a}]}$ Elizabeth A. Hillard, ${ }^{*[\mathrm{a}]}$ Michel Huché,${ }^{[\mathrm{a}]}$ \\ Christian G. Hartinger, ${ }^{[\mathrm{b}]}$ Frédéric de Montigny, ${ }^{[\mathrm{a}]}$ Marie-Aude Plamont, ${ }^{[\mathrm{a}]}$ Anne Vessières, ${ }^{[\mathrm{a}]}$ \\ and Gérard Jaouen ${ }^{[\mathrm{a}]}$
}

[a] M. Görmen, Dr. P. Pigeon, Dr. S. Top, Dr. E. A. Hillard, Dr. M. Huché, Dr. F. de Montigny, M.-A. Plamont, Dr. A. Vessières, Prof. G. Jaouen Chimie ParisTech (Ecole Nationale Supérieure de Chimie de Paris) Laboratoire Charles Friedel, UMR CNRS 722311 rue Pierre et Marie Curie, 75231 Paris Cedex 05 (France) Fax: (+33) 143-260-061 E-mail: siden-top@ chimie-paristech.fr elizabeth-hillard@ chimie-paristech.fr

[b] Dr. C. G. Hartinger Institute of Inorganic Chemistry University of Vienna, Waehringer Str. 42, 1090 Vienna (Austria)

Keywords: bioorganometallic chemistry, cell culture, cytotoxicity, drug discovery, ferrocenes

Herein we report the antiproliferative effects of a series of 28 compounds against the MDAMB-231 breast cancer cell line, including the synthesis of seven new [3]ferrocenophanyl and four new ferrocenyl compounds. For each $p$-R-phenyl substitution pattern investigated, the [3]ferrocenophanyl derivatives were more cytotoxic than the corresponding ferrocenyl derivative, with the highest activity found for compounds with protic substituents. Theoretical calculations of the HOMO-LUMO gap for the molecules in the $\mathrm{Fe}^{3+}$ oxidation state suggest a higher reactivity for the [3]ferrocenophanyl derivatives. A lead compound from each series, a [3]ferrocenophanyl and a ferrocenyl compound, possessing two phenol groups, were screened against the NCI/DTP 60-cell-line panel. The mean activity over all cell lines was better than cisplatin for both compounds, and both compounds showed subpanel selectivity for leukemia, CNS cancer, and renal cancer. Low systemic toxicity and lack of interaction with DNA (when in the reduced form), suggest that the compounds may act as prodrugs. 


\section{Introduction}

The development of organometallic compounds for cancer therapeutics is one of the fastest growing areas of bioorganometallic chemistry. ${ }^{[1-4]}$ These molecules can be generally categorized based on their mode of action, for example those where direct interaction of the metal with a biological target, such as DNA or proteins after ligand hydrolysis, is implicated. ${ }^{[5-9]}$ Modeled after the action of cisplatin, these metal-centered organometallic compounds, notably containing ruthenium ${ }^{[9,10]}$ or titanium, ${ }^{[1]}$ possess judiciously chosen ligands or substituents on the phenyl ring to optimize the pharmacokinetic properties of the molecule. Another class demonstrates the enthusiasm researchers have for grafting metallocenes and metal carbonyls to a variety of biomolecules to modify their biological effects. ${ }^{[12]}$ These therapeutic bioconjugates include steroidal $^{[13-15]}$ and nonsteroidal ${ }^{[16-23]}$ endocrine modulators, natural products, ${ }^{[24-27]}$ and others. ${ }^{[28-34]}$ In these cases, the often covalently grafted organometallic unit is usually inert to ligand substitution, but potentiates the activity of the biomolecule via modification of the pharmacokinetic profile or acts as a structural mimic. ${ }^{[35]}$ A variety of other compounds are between these two classes, possessing labile biomolecule ligands, such as nucleobases. ${ }^{[33,36-41]}$ Currently in press, the book "Medicinal Organometallic Chemistry" demonstrates that the growth of structural and mechanistic diversity of organometallic compounds for cancer therapy is in full bloom. ${ }^{[42]}$

Among organometallic compounds based on endocrine modulators, the most active and well-studied are the ferrocenyl derivatives of tamoxifen (with or without the side chain present). ${ }^{[43]}$ We have shown that the reversible ferrocene/ferricenium redox couple can catalyze the intramolecular formation of quinones when the ferrocenyl and phenol groups are linked by a conjugated system. ${ }^{[4]}$ This mechanism is not limited to phenolic compounds: ferrocenyl moieties conjugated to an aniline or acetanilide group also show high activity against cancer cells, with $\mathrm{IC}_{50}$ values of the order of $10^{-7} \mathrm{M}^{[45]}$ The structural requirements for activity seem to be 1) the presence of a ferrocene group, 2) a conjugated linker, 3) aromatic para substitution by a protic function, and 4) an ethyl group residing on the same carbon as the ferrocene group.

As a part of our studies of organometallic compounds with this motif, [3]ferrocenophanes have recently emerged as a class of notable antiproliferative agents. The [3]ferrocenophane 
structure consists of a ferrocene, where the two cyclopentadienyl rings are linked by a three atom bridge, in this case carbon atoms. Molecules possessing this motif have been discussed in reviews, ${ }^{[46,47]}$ and have been studied in the context of their structures, ${ }^{[48-57]}$ catalytic properties, ${ }^{[56,58-63]}$ and conjugation to biomolecules, ${ }^{[64,65]}$ inter alia. For the [3]ferrocenophane compounds based on the tamoxifen skeleton, it is supposed that their biological activity is due to a mechanism of activation similar to that of their ferrocenyl analogues. Among organometallic compounds studied so far, the highest in vitro cancer activity is exhibited by those based on the 1-(diphenylmethylidene)-[3]ferrocenophane skeleton, with para substitution on both phenyl rings ${ }^{[66-68]}$ (Table 1).

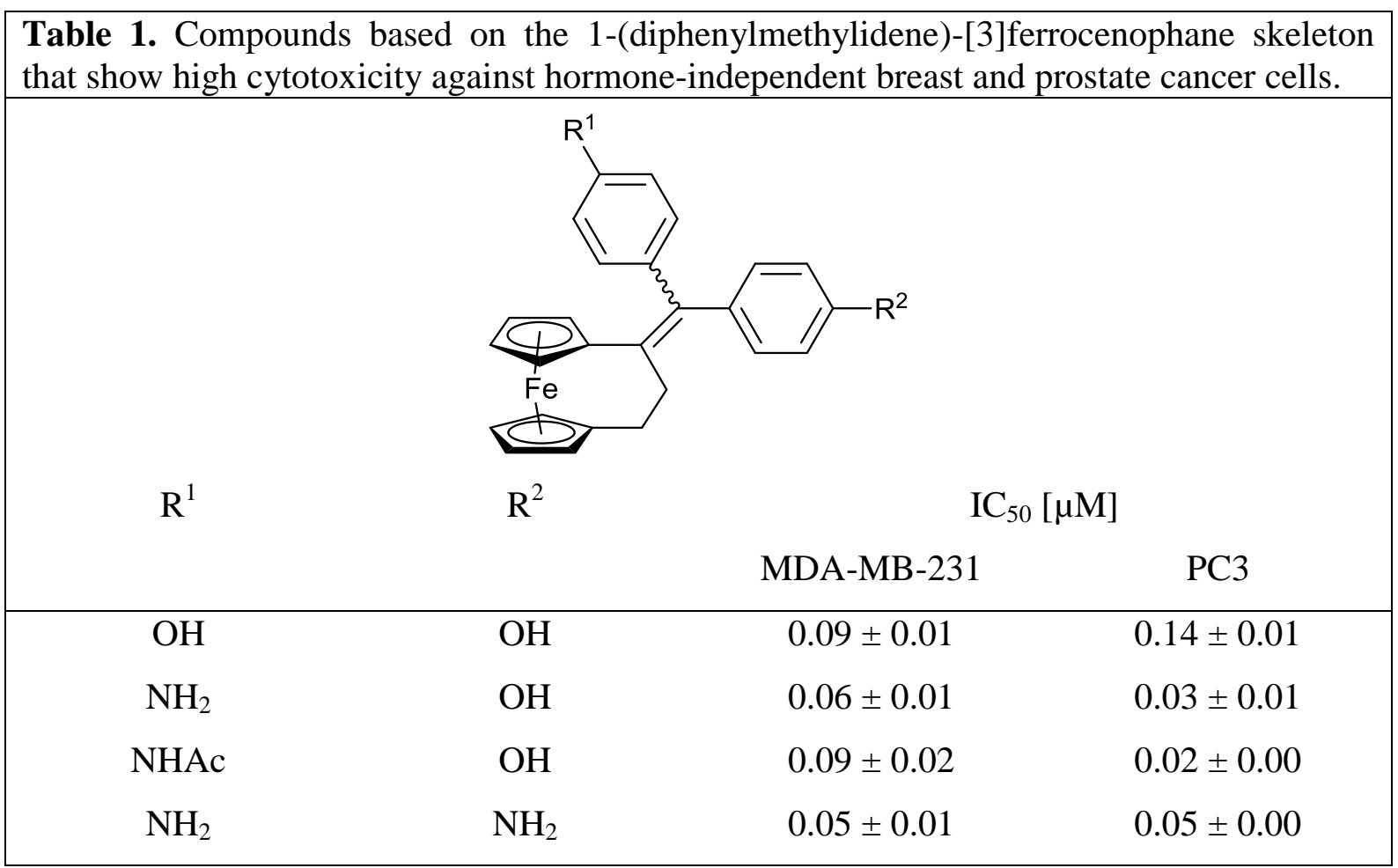

For compounds possessing a phenol, an aniline, and/or an acetanilide, with all other parameters being equal, the presence of a [3]ferrocenophane in lieu of an $n$-propylferrocene yields more toxic molecules. As this phenomenon has been studied with a limited number of compounds, herein we report the results from a 28-molecule structure-activity study, which involved the synthesis and biological evaluation of 11 new compounds. These molecules are all based on the 1-(diphenylmethylidene)-[3]ferrocenophane or the 1- 
(diphenylmethylidene)ethylferrocene skeleton and were tested on hormone-independent MDA-MB-231 cells. A lead compound (with two hydroxy substituents) from each series was further evaluated by the National Cancer Institute Developmental Therapeutics Program (NCI/DTP) against their panel of 60 human tumor cell lines, and a COMPARE analysis was performed on these results. Cytotoxicity results have also been interpreted in light of theoretical calculations on the HOMO-LUMO gap of the oxidized molecule $\left(\mathrm{Fc}^{+}\right)$and the interaction with DNA of a reduced molecule.

\section{Results}

\section{Synthesis}

A simple and key step to obtain the desired tetrasubstituted olefins involves a McMurry crosscoupling reaction between the appropriate benzophenone and [3]ferrocenophan-1-one or propionyl ferrocene to generate the [3]ferrocenophanes (1a-17a) and the corresponding ferrocenes (1b-15b), respectively (Scheme 1, Table 2). The reaction time depends on the substituents and can vary from 90 min to three days. One caveat of the McMurry reaction is that there is a competition between the formation of the desired cross-coupled product and the two homo-coupled compounds, and this is reflected in the variety of the reaction yields. In most cases, the reactions with [3]ferrocenophan-1-one were more efficient than those using propionyl ferrocene. This can be attributed to the great avidity propionyl ferrocene shows for itself, resulting in a relatively high proportion of homo-coupled diferrocenyl species under McMurry conditions.

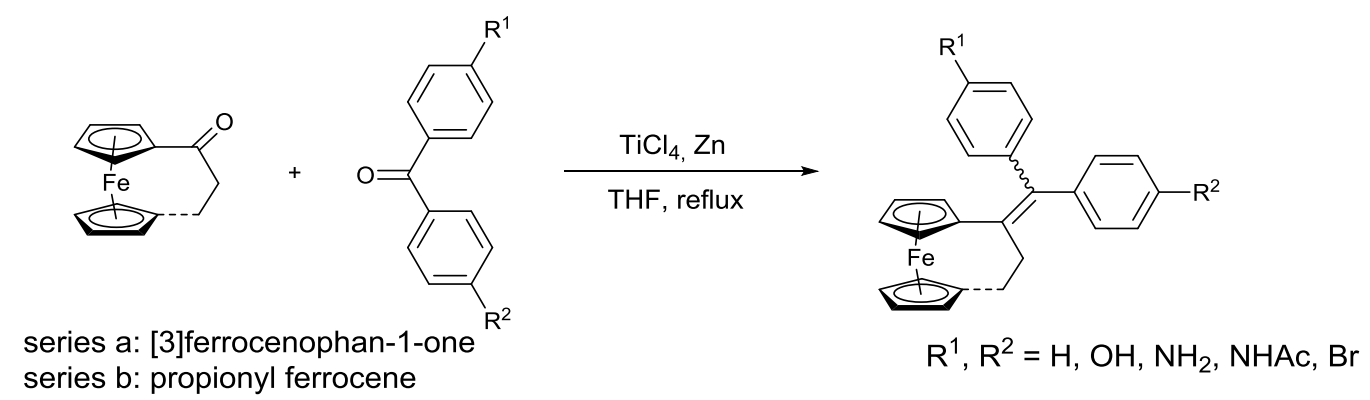

Scheme 1. General scheme of the McMurry cross-coupling reaction. 


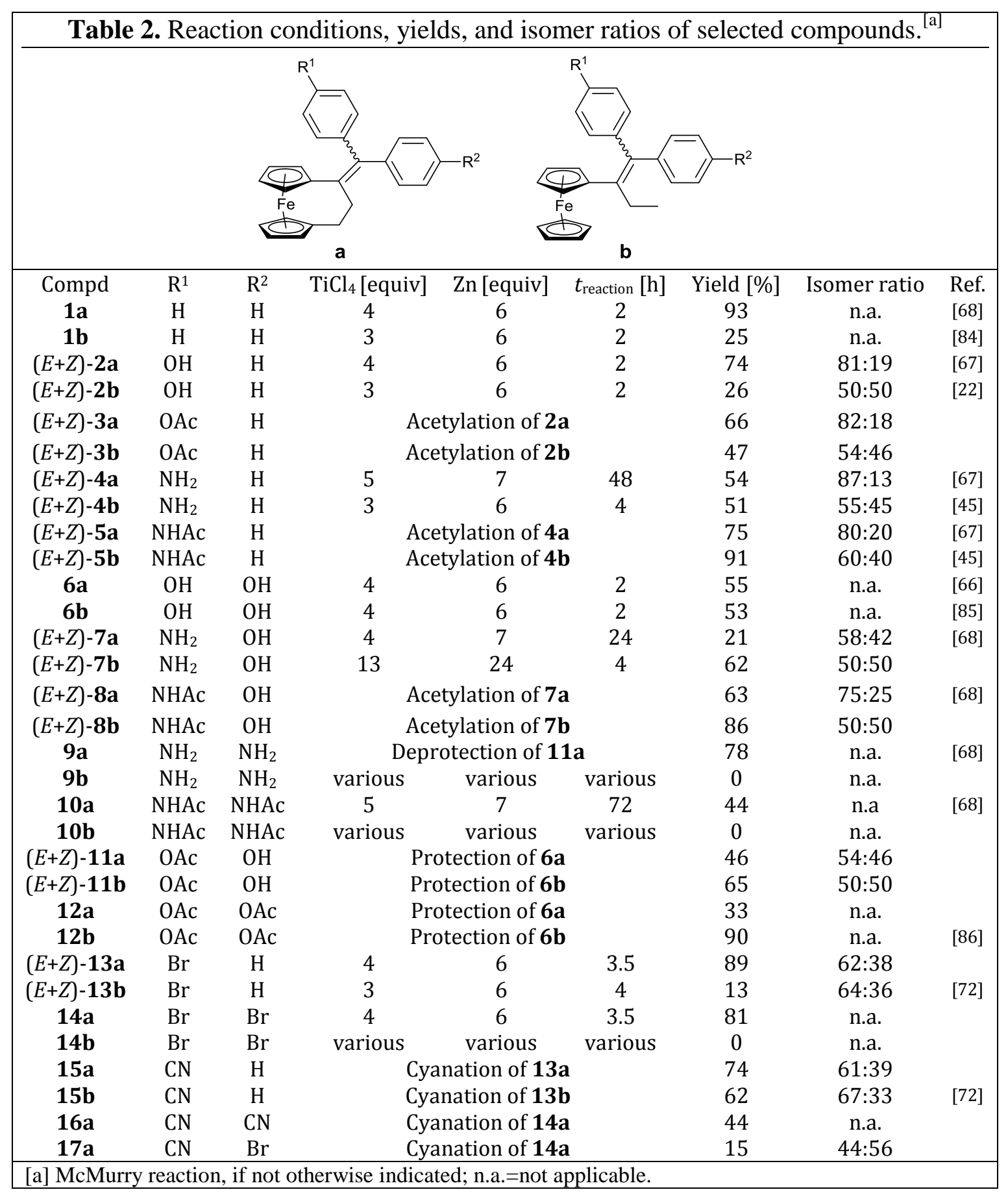

In some cases, the coupling reaction did not yield the desired product. For example, the reaction between propionyl ferrocene and 4,4'-diaminobenzophenone did not lead to any trace of the expected 2-ferrocenyl-1,1-bis(4-aminophenyl)but-1-ene, 9b. Attempts to similarly obtain the NHAc-substituted compound 10b were likewise unsuccessful. However, when 
propionyl ferrocene was replaced by [3]ferrocenophan-1-one, the amido compound 10a was obtained in moderate yield, although only after a reaction time of $72 \mathrm{~h}$. On the other hand, the reaction between [3]ferrocenophan-1-one and 4,4'-diaminoacetophenone did not yield any desired product and therefore 9a was instead obtained by deacetylation of 10a. The McMurry reaction between propionyl ferrocene and the dibromobenzophenone also failed to yield the desired product 14b. This is surprising, as the reaction between [3]ferrocenophan-1-one and dibromobenzophenone gave the desired 14a in high yield. It should be mentioned that the failure of the McMurry reaction was only observed for the disubstituted compounds; the monosubstituted $\mathrm{NH}_{2}$ (4), NHAc (5) and $\mathrm{Br}$ (13) derivatives were obtained in both the ferrocenophane and ferrocene series without difficulty.

We routinely used an excess of $\mathrm{TiCl}_{4}$ for the McMurry reaction, between three and five equivalents, and a 1:1 proportion of the ferrocenyl ketone and benzophenone. In the case of 4a and 10a, five equivalents of $\mathrm{TiCl}_{4}$ were used, because our experience shows that the nitrogen-containing benzophenones are less reactive than the corresponding hydroxy benzophenones. This is also reflected in the long reaction time necessary to obtain these compounds. In some cases amino-substituted compounds were obtained by an in situ reduction of nitro-substituted benzophenones. We compared the reactions using such reagents for the synthesis of $\mathbf{4 a}$ and $\mathbf{4 b}$. For $\mathbf{4 a}$, 4-aminobenzophenone gave a yield of $54 \%$ after two days of reaction and 4-nitrobenzophenone gave a yield of $21 \%$. For $\mathbf{4 b}$, the trend was reversed, with yields of $26 \%$ and $51 \%$, using 4-amino and 4-nitrobenzophenone, respectively. In the case of $\mathbf{7 a}$ and $\mathbf{7 b}, 4$-nitro-4-hydroxybenzophenone, formed via a Friedel-Crafts reaction, was used directly. ${ }^{[68]}$ In this case, a large excess of $\mathrm{Zn}$ was used to reduce the $\mathrm{NO}_{2}$ to $\mathrm{NH}_{2} \cdot{ }^{[69]}$
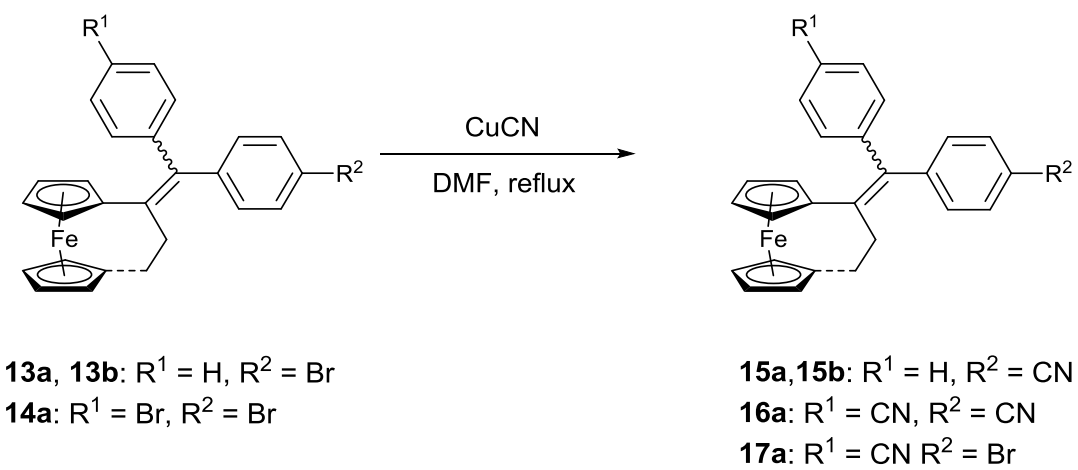

13a, 13b: $R^{1}=H, R^{2}=B r$

14a: $R^{1}=B r, R^{2}=B r$ 16a: $R^{1}=C N, R^{2}=C N$

17a: $\mathrm{R}^{1}=\mathrm{CN} \mathrm{R} \mathrm{R}^{2}=\mathrm{Br}$ 
Scheme 2. Cyanation of monosubstituted and disubstituted bromo derivatives.

Nitriles 15a, 15b, and 16a were obtained by treating the corresponding bromo derivatives with $\mathrm{CuCN}$ (Scheme 2). Compound 16b was inaccessible, as its precursor 14b was not obtained via the McMurry reaction as previously discussed. In our hands the cyanation of 14a was incomplete, giving access to the mixed $\mathrm{CN} / \mathrm{Br}$ derivative $17 \mathbf{a}$ in $15 \%$ yield with a 44:56 isomer ratio (this compound was not tested for its antiproliferative effects).

\section{X-ray crystallography of $7 \mathrm{~b}$}

X-ray quality crystals of E-7b were obtained from a mixture of $\mathrm{E}$ and $\mathrm{Z}$ isomers in an EtOH/ $\mathrm{H}_{2} \mathrm{O}$ solution by slow evaporation. Reflections were recorded using $\mathrm{MoK}_{\alpha}$ radiation at $200 \mathrm{~K}$. The ORTEP diagram, with selected bond distances and angles, is shown in Figure 1 and crystallographic data are available from the Cambridge Crystallographic Data Centre (CCDC-783005). ${ }^{[70]}$ The crystal structure shows almost no distortion around the ferrocene group, but a significant deviation from planarity around the ethylene center, with an average torsion angle of $13^{\circ}$. The phenyl rings are twisted out of the plane created by $\mathrm{C} 1-\mathrm{C} 15-\mathrm{C} 21$ by 52.8 and $48.1^{\circ}$ which is typical of such compounds. ${ }^{[67,71]}$

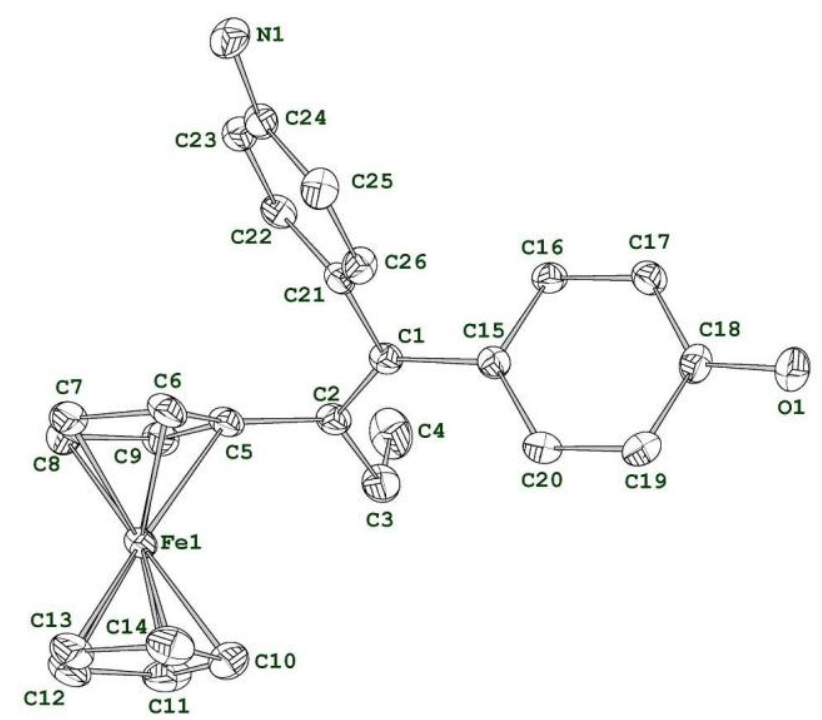

Figure 1. ORTEP diagram of $(E)-7 \mathbf{b}$. Thermal ellipsoids shown at 50\% probability level, and hydrogen atoms have been omitted for clarity. Selected bond distances $(\AA)$ and bond angles $\left({ }^{\circ}\right): \mathrm{Fe} 1-\mathrm{C}_{\mathrm{Cp}}=2.061(2), \quad \mathrm{C} 1-\mathrm{C} 2=1.372(2), \quad \mathrm{C} 18-\mathrm{O} 1=1.376(2), \quad \mathrm{C} 24-\mathrm{N} 1=1.420(2), \quad \mathrm{Fe} 1-$ 
$\mathrm{C}_{\text {Centroid }}=179.25, \mathrm{Cp}-\mathrm{Cp}=2.34 ; \mathrm{C} 3-\mathrm{C} 2-\mathrm{C} 1-\mathrm{C} 21=164.1, \mathrm{C} 5-\mathrm{C} 2-\mathrm{C} 1-\mathrm{C} 15=169.8, \mathrm{C} 3-\mathrm{C} 2-\mathrm{C} 1-$ $\mathrm{C} 15=\_13.54, \mathrm{C} 5-\mathrm{C} 2-\mathrm{C} 1-\mathrm{C} 21=-12.58$.

Table 3. Cytotoxicity of compounds 1-16 against hormone-independent MDAMB-231 breast cancer cells.

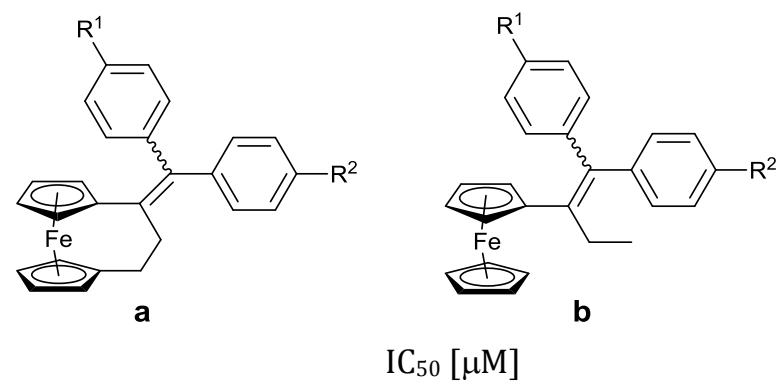

\begin{tabular}{|c|c|c|c|c|c|}
\hline Compd & $\mathrm{R}^{1}$ & $\mathrm{R}^{2}$ & $\begin{array}{l}\text { Ferrocenophane } \\
\text { derivatives (a) }\end{array}$ & $\begin{array}{c}\text { Ferrocene } \\
\text { derivatives }(\mathbf{b})\end{array}$ & Cytotoxicity ratio [d] \\
\hline 1 & $\mathrm{H}$ & $\mathrm{H}$ & $0.92 \pm 0.11$ & $7.54 \pm 0.7$ & 8.2 \\
\hline$(E+Z)-2$ & $\mathrm{OH}$ & $\mathrm{H}$ & $0.47 \pm 0.06$ & $1.54 \pm 0.13$ & 3.3 \\
\hline$(E+Z)-3$ & $\mathrm{OAc}$ & $\mathrm{H}$ & $0.26 \pm 0.004$ & $1.97 \pm 0.2$ & 7.6 \\
\hline$(E+Z)-4$ & $\mathrm{NH}_{2}$ & $\mathrm{H}$ & $0.21 \pm 0.03$ & $0.86 \pm 0.04$ & 4.1 \\
\hline$(E+Z)-5$ & NHAc & $\mathrm{H}$ & $0.47 \pm 0.04$ & $0.65 \pm 0.01$ & 1.4 \\
\hline 6 & $\mathrm{OH}$ & $\mathrm{OH}$ & $0.089 \pm 0.006$ & $0.64 \pm 0.06$ & 7.2 \\
\hline$(E+Z)-7$ & $\mathrm{NH}_{2}$ & $\mathrm{OH}$ & $0.061 \pm 0.005$ & $0.55 \pm 0.05$ & 9.0 \\
\hline$(E+Z)-8$ & NHAc & $\mathrm{OH}$ & $0.092 \pm 0.019$ & $0.56 \pm 0.06$ & 6.1 \\
\hline 9 & $\mathrm{NH}_{2}$ & $\mathrm{NH}_{2}$ & $0.047 \pm 0.01$ & n.o. [b] & - \\
\hline 10 & NHAc & NHAc & $5.64 \pm 1.13$ & n.o. $\left.{ }^{b}\right]$ & - \\
\hline$(E+Z)-11$ & $\mathrm{OAc}$ & $\mathrm{OH}$ & $0.049 \pm 0.003$ & $0.42 \pm 0.03$ & 8.6 \\
\hline 12 & $\mathrm{OAC}$ & $\mathrm{OAc}$ & $0.044 \pm 0.001$ & $0.64 \pm 0.05$ & 14.5 \\
\hline$(E+Z)-13$ & $\mathrm{Br}$ & $\mathrm{H}$ & $2.93 \pm 0.62$ & $>10^{[a]}$ & $>3.4$ \\
\hline 14 & $\mathrm{Br}$ & $\mathrm{Br}$ & $>10$ [a] & n.o. $\left.{ }^{b b}\right]$ & - \\
\hline 15 & $\mathrm{CN}$ & $\mathrm{H}$ & $0.85 \pm 0.07(E+Z)$ & $10.9 \pm 0.2(Z)$ & 12.8 \\
\hline 16 & $\mathrm{CN}$ & $\mathrm{CN}$ & $7.98 \pm 1.2$ & n.s. [c] & - \\
\hline \multicolumn{6}{|c|}{$\begin{array}{l}\text { [a] Precise } \mathrm{IC}_{50} \text { values were not obtained because of low activity in the single-dose } \\
\text { test }\left(\mathbf{1 3 b} \text { : } 86 \% \text { cell viability at } 10^{-5} \mathrm{M}, \mathbf{1 4 a}: 89 \% \text { cell viability at } 10^{-5} \mathrm{M}\right) ;[\mathrm{b}] \\
\text { n.o.=molecule not obtained; [c] n.s.=molecule not synthesized; [d] } \mathrm{IC}_{50}(\mathbf{b}) / \mathrm{IC}_{50}(\mathbf{a}) \text {. }\end{array}$} \\
\hline
\end{tabular}

\section{Antiproliferative effects on MDA-MB-231 cells}

All new compounds, except 17a, were screened for their activity against the MDA-MB-231 human breast cancer cell line. This line is hormone independent, that is, it does not express the estrogen receptor, and therefore cell culture results are not confounded with estrogenic or antiestrogenic effects. Cells were incubated with at least three concentrations of the test compound for five days, and cell viability was determined by the staining of proteins in living cells. Cytotoxicity results ( $\mathrm{IC}_{50}$ values) are given in Table 3. In all cases, the ferrocenophane derivatives are more cytotoxic than their ferrocenyl analogues. In the case of the NHAc- 
substituted compound $\mathbf{5}$, the difference between the two compounds is small, but significant. Conversely, the diacetoxy compound 12a is almost 15 times more potent than its ferrocenyl analogue. The difference in cytotoxicity results for the nitriles $\mathbf{1 5 a}$ and $\mathbf{1 5 b}$ is even more dramatic than shown in Table 3. With an $\mathrm{IC}_{50}$ value of $60 \mu \mathrm{M}$, the $E$ isomer of $\mathbf{1 5 b}$ is much less active than its $Z$ isomer. ${ }^{[72]}$ Therefore, given a 50:50 mixture of isomers for $\mathbf{1 5 b}$, one could predict a cytotoxicity ratio of approximately 40 .

\section{Antiproliferative effects of $6 a$ and $6 b$ on the NCI cell line panel}

Compounds $6 \mathbf{a}$ and $\mathbf{6 b}$ were selected for further study on the human tumor cell line panel of the Developmental Therapeutics Program of the National Cancer Institute (Bethesda, MD, USA). ${ }^{[73]}$ The compounds were tested on approximately 60 cell lines within nine tumor type subpanels. The cells were treated for $48 \mathrm{~h}$ at five concentrations ranging from 0.01 to $100 \mu \mathrm{M}$. Three endpoints were calculated: $\mathrm{GI}_{50}$ (the concentration where the compound inhibits cell growth by 50\%), TGI (the concentration at which the compound inhibits cell growth by 100 $\%$ ), and $\mathrm{LC}_{50}$ (the concentration at which the drug decreases the original cell number by $50 \%$ ), shown in Figure 2, as well as the MG-MID (full-panel mean-graph midpoint). Compounds $6 \mathbf{a}$ and $\mathbf{6 b}$ have a broad spectrum of activity, with MG-MID values (representing the average of the MG-MIDs for two experiments, using almost identical panels) lower than those for cisplatin (Table 4). The correlation between the full-panel results for the two compounds was $78 \%$ for $\mathrm{GI}_{50}, 58 \%$ for TGI, and $58 \%$ for $\mathrm{LC}_{50}$ values.

\begin{tabular}{|l|cc|}
\hline \multicolumn{4}{|c|}{ Table 4. Full-panel mean-graph midpoint (MG-MID) $\mathrm{GI}_{50}, \mathrm{TGI} \mathrm{LC}_{50}$ values of } \\
compounds in the NCI cell panel.[a]
\end{tabular}

The $\mathrm{GI}_{50}$ results varied over approximately three orders of magnitude for $6 \mathbf{a}$, and two orders of magnitude for $\mathbf{6 b}$, suggesting a more varied selectivity profile for $\mathbf{6 a}$. Comparing the mean $\mathrm{GI}_{50}$ for each histological subpanel gives an indication of tumor selectivity, and a compound is considered selective for a tumor type if the mean $\mathrm{GI}_{50}$ value is below the MG- 
MID for all cell lines (here $0.18 \mu \mathrm{M}$ for $\mathbf{6 a}$ and $0.52 \mu \mathrm{M}$ for $\mathbf{6 b}$ ). Table 5 shows the mean values over each subpanel for two different experiments. Compound 6a is selective for leukemia, CNS cancer, and renal cancer, and was particularly active against melanoma M14, renal cancer ACHN, and CNS cancer SF-539, with two experiments giving $\mathrm{GI}_{50}$ values less than $20 \mathrm{nM}$. Compound $\mathbf{6 b}$ also showed selectivity for leukemia, CNS cancer, and renal cancer. Similar to $\mathbf{6 a}$, this compound was particularly active against ACHN and SF-539, but also against UACC-62 melanoma, HL60 (TB), and SR leukemia cell lines with GI $_{50}$ values falling below $0.2 \mu \mathrm{M}$ for two experiments. Compound $\mathbf{6 a}$ was more active than $\mathbf{6 b}$ for every subpanel of cells. The most dramatic difference in activity was noted for the renal cancer subpanel.

\begin{tabular}{|c|c|c|c|c|c|}
\hline Cell panel & $\mathbf{6 a}(\exp .1)$ & $\mathbf{6 a}(\exp .2)$ & $\mathbf{6 b}(\exp .1)$ & $\mathbf{6 b}(\exp .2)$ & $6 b / 6 a$ \\
\hline Leukemia & 0.14 & 0.11 & 0.27 & 0.17 & 1.8 \\
\hline NSCL Cancer & 0.31 & 0.16 & 0.84 & 0.50 & 2.9 \\
\hline Colon Cancer & 0.40 & 0.34 & 0.80 & 0.61 & 1.9 \\
\hline CNS Cancer & 0.074 & 0.092 & 0.31 & 0.29 & 3.6 \\
\hline Melanoma & 0.19 & 0.15 & 0.83 & 0.55 & 4.1 \\
\hline Ovarian Cancer & 0.43 & 0.30 & 1.09 & 0.53 & 2.2 \\
\hline Renal Cancer & 0.072 & 0.048 & 0.43 & 0.20 & 5.3 \\
\hline Prostate Cancer & 0.41 & $0.048^{[b]}$ & 0.78 & 0.56 & 1.6 \\
\hline Breast Cancer & 0.58 & 0.49 & 1.0 & 0.84 & 1.7 \\
\hline
\end{tabular}

\begin{tabular}{|c|c|c|c|c|c|c|}
\hline \multirow[t]{2}{*}{ Compd } & \multirow[t]{2}{*}{ Endpoint } & \multicolumn{3}{|c|}{ Molecule with best correlation } & \multirow{2}{*}{$\begin{array}{l}\text { Tamoxifen } \\
\text { PCC }\end{array}$} & \multirow{2}{*}{$\begin{array}{l}\text { Cisplatin } \\
\text { PCC }\end{array}$} \\
\hline & & Name & PCC & Mechanism & & \\
\hline \multirow{3}{*}{$6 a$} & $\mathrm{GI}_{50}$ & topotecan & 0.70 & topoisomerase I inhibitor & 0.06 & 0.51 \\
\hline & TGI & $3 \mathrm{HP}$ & 0.62 & DNA antimetabolite & 0.15 & 0.50 \\
\hline & $\mathrm{LC}_{50}$ & bleomycin & 0.72 & DNA strand breaks & 0.36 & 0.38 \\
\hline \multirow{3}{*}{$6 \mathbf{b}$} & $\mathrm{GI}_{50}$ & $\begin{array}{l}\text { aphidicolin } \\
\text { glycinate }\end{array}$ & 0.81 & DNA antimetabolite & 0.23 & 0.59 \\
\hline & TGI & topotecan & 0.67 & topoisomerase II inhibitor & 0.39 & 0.38 \\
\hline & $\mathrm{LC}_{50}$ & tamoxifen & 0.56 & $\begin{array}{l}\text { selective estrogen receptor } \\
\text { modulator }\end{array}$ & 0.56 & 0.40 \\
\hline
\end{tabular}

To gain insight into a possible mechanism of action for $\mathbf{6 a}$ and $\mathbf{6 b}$, a COMPARE analysis $^{[74]}$ was carried out against the NCI/DTP Standard Agents database, a collection of 
171 known molecules. The three endpoints for each seed molecule were compared with the same endpoint for the database molecules $\left(\mathrm{GI}_{50}\right.$, TGI, and $\left.\mathrm{LC}_{50}\right)$. The molecule with the best correlation [Pearson correlation coefficient (PCC)] and the values for tamoxifen and cisplatin are given in Table 6. The full-panel correlations with cisplatin and tamoxifen were weak $\left(\mathrm{R}^{2}<0.6\right)$ for all endpoints. The best PCCs for each endpoint belong to molecules which inhibit DNA replication or cause DNA damage.

Each standard agent in the database appears with an associated mechanism: alkylating agent, antimitotic agent, DNA antimetabolite, RNA/DNA antimetabolite, topoisomerase II inhibitor, or not given/other. Averaging over the top 20 hits in each category over each endpoint, the dominant suggested mechanism for 6a is RNA and/or DNA antimetabolite (36 $\%$ ), followed by an DNA alkylation (32\%), not given/other (20\%), topoisomerase II inhibition (9\%), or as a antimitotic agent (3\%). The dominant suggested mechanism for $\mathbf{6 b}$ was DNA alkylation (36 \%), followed by acting as a RNA and/or DNA antimetabolite (22 \%), topoisomerase II inhibition (18\%), not given/other (14\%), or as an antimitotic agent (9\%). 


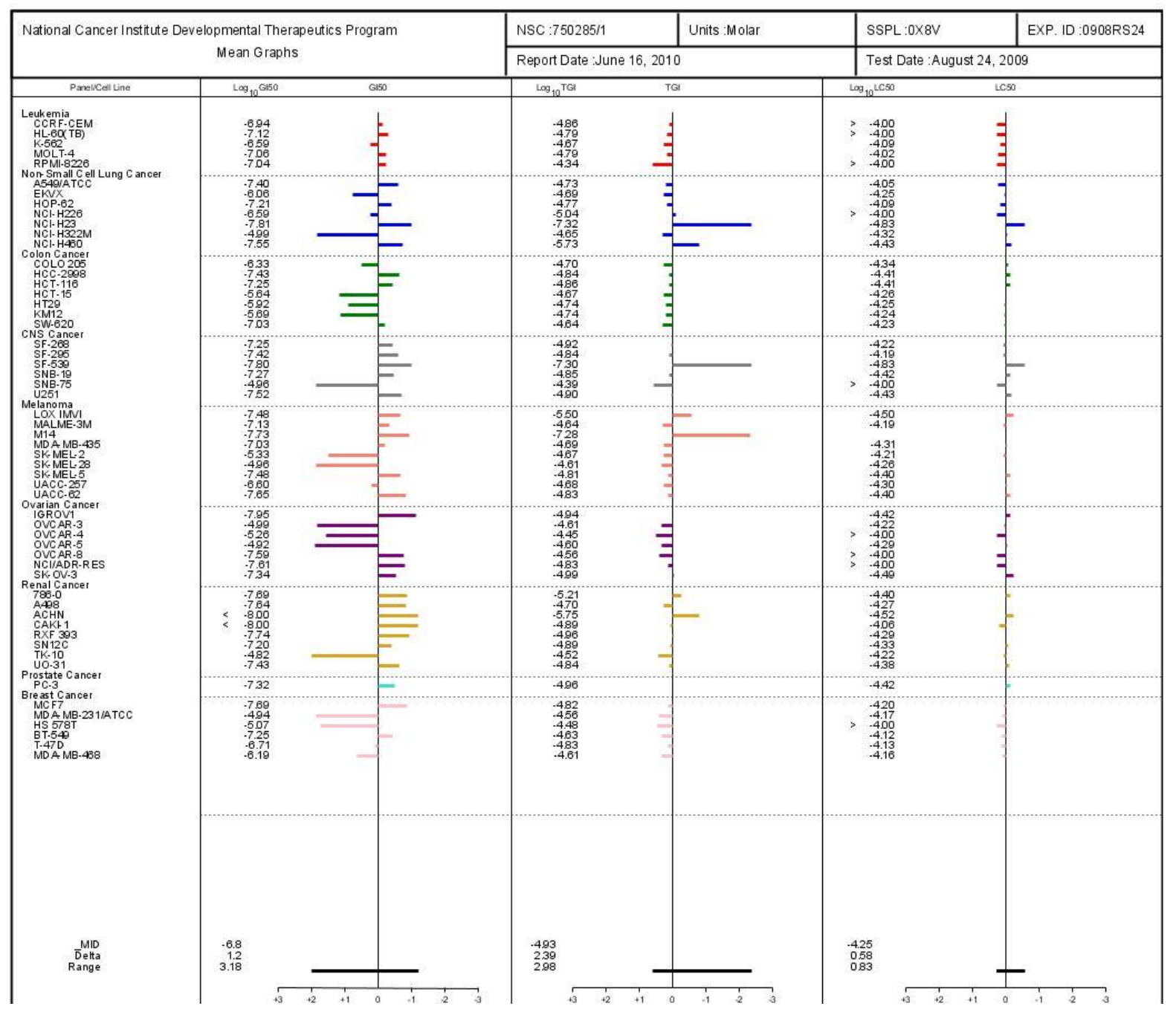




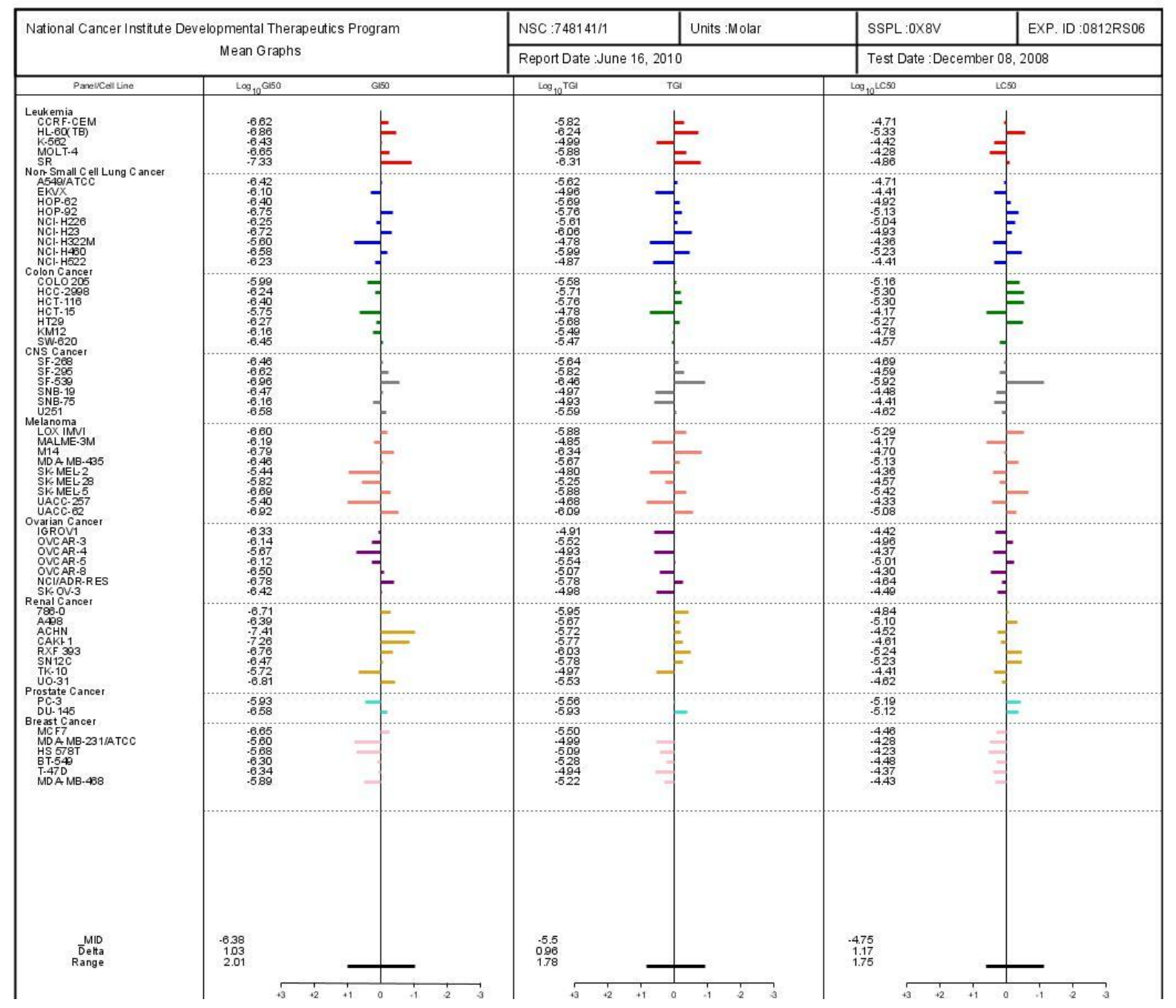

Figure 2. Mean graphs for compounds a) 6a and b) $\mathbf{6 b}$ from the National Cancer Institute Developmental Therapeutic Program; data from one experiment shown.

\section{Acute toxicity of $6 \mathrm{a}$ and $6 \mathrm{~b}$}

Mice were treated by interperitoneal injection of $\mathbf{6 a}$ and $\mathbf{6 b}$ in DMSO by the NCI/DPT program. ${ }^{[75]}$ One mouse was injected with $400 \mathrm{mg} \mathrm{kg}^{-1}$, the second with $200 \mathrm{mg} \mathrm{kg}^{-1}$, and the third with $100 \mathrm{mg} \mathrm{kg}^{-1}$ of the test compound. The mice were observed for two weeks and sacrificed if more than $20 \%$ weight loss or other signs of toxicity were noted. For $\mathbf{6 a}$, the mice given doses of 400 and $200 \mathrm{mg} \mathrm{kg}^{-1}$ were sacrificed. For $\mathbf{6 b}$, only the mouse given the highest dose of $400 \mathrm{mg} \mathrm{kg}^{-1}$ was sacrificed. Thus the determined maximum tolerated dose was 100 $\mathrm{mg} \mathrm{kg}^{-1}$ for $\mathbf{6 a}$ and $200 \mathrm{mg} \mathrm{kg}^{-1}$ for $\mathbf{6 b}$. 


\section{Interaction of $6 b$ with nucleotides}

Compound $6 \mathbf{b}(0.5 \mathrm{mM})$ was incubated in $10 \mathrm{mM} \mathrm{NaH} \mathrm{PO}_{4}-\mathrm{Na}_{2} \mathrm{HPO}_{4}$ buffer (pH 7.4) with the nucleotides 5'-GMP, 5'-AMP, or 5'-CMP to obtain molar ratios of 1:2 complex/nucleotide). Analyses of the solutions were performed on a Hewlett-Packard ${ }^{3 \mathrm{D}}$ Capillary Electrophoresis system equipped with a diode array detector at $\lambda 200 \mathrm{~nm}$ for $10 \mathrm{~h}$. As shown in Figure 3, there is no significant change in the intensity of the peaks over time, indicating that no adducts between the nucleotides and $\mathbf{6 b}$ were formed. Similar studies with transition metal complexes featuring leaving groups, including cisplatin and $\mathrm{Pt}^{\mathrm{II}}$ analogues, ${ }^{[76]}$ $\mathrm{Ru}$ anticancer drug candidates and developmental compounds, ${ }^{[77]}$ exclusively form adducts with nucleobases, normally with highest binding preference to the $\mathrm{N} 7$ atoms of guanine and adenine. ${ }^{[78]}$

\section{Calculation of HOMO-LUMO gaps for oxidized molecules}

Relative differences in the HOMO-LUMO gaps of molecules can be used as a predictor of their reactivity. ${ }^{[79,80]}$ Using as a starting point our proposal that quinone methide metabolites of the test molecules are the toxic species, and that quinone methide formation involves an initial oxidation of ferrocene to ferricenium, we calculated the HOMO-LUMO gap of the oxidized (ferricenium) forms of the molecules, Table 7. The HOMO-LUMO gap of the ferrocenophanes is quite small, with an average of $1.6 \mathrm{eV}$ and a range of 1.4-1.9 eV. The calculated HOMO-LUMO gaps for the oxidized ferrocene compounds are more variable, but consistently larger, with an average HOMO-LUMO gap of $6.2 \mathrm{eV}$ and a range of 3.9 to 7.2 $\mathrm{eV}$.

\section{Discussion}

The [3]ferrocenophane series is more active than the ferrocene series on the MDA-MB-231 cells and the 60 cell line panel overall. We previously proposed that quinone methides, formed via initial oxidation of the ferricenium moiety, could be the active metabolite in the cell, and higher cytotoxicity of the ferrocenophane molecules is consistent with this mechanism for the following reasons. Firstly, the additional electron density imparted to the ferrocene group by the bridge lowers the oxidation potential of the ferrocene, the first step in the proposed mechanism. ${ }^{[66]}$ Secondly, due to the rigid conformation of the bridge, the formed quinone methide is expected to be highly strained and reactive. ${ }^{[67]}$ Thirdly, Hartree-Fock 
calculations suggest that the difference in activity between the ferrocenophane and ferrocene series could be due to differences in the HOMO and LUMO energy levels for the oxidized $\left(\mathrm{Fc}^{+}\right)$form of the compound. With a narrower HOMO-LUMO gap, the oxidized ferrocenophane complexes can more easily attain the first excited state and are therefore more reactive. These compounds could evolve to the quinone methide, when possible, or another reaction such as fragmentation giving rise to toxic molecules.

Indeed, the compounds that can be oxidized to a quinone methide, such as the hydroxy compounds $\mathbf{2}$ or $\mathbf{6}$, or quinone imines, such as $\mathbf{4}$ or $\mathbf{9}$, are very active. Although the best activity was provided by the diacetoxy $\mathbf{1 2 a}$, this species should be easily transformed into $\mathbf{6 a}$ by hydrolysis in the cell. By contrast, comparison of the diamino compound 9a with diacetamido 10a shows a dramatic decrease in activity from 0.047 to $5.64 \mu \mathrm{M}$, probably because the hydrolysis of the acetamido compound is more difficult than the hydrolysis of acetoxy compound. The presence of an electron withdrawing group such as $\mathrm{Br}$ or $\mathrm{CN}$ decreases the antiproliferative activity for the ferrocene series, as previously observed, ${ }^{[72]}$ and also for the [3]ferrocenophane compounds.

There are also several indications that these compounds act as prodrugs, that is, innocuous compounds which are activated in the cell to form toxic species. For example, NCI/DPT acute toxicity tests on mice for $\mathbf{6 a}$ and $\mathbf{6 b}$ showed mouse death only at high drug concentrations (200 mg kg ${ }^{-1}$ and $400 \mathrm{mg} \mathrm{kg}^{-1}$, respectively). ${ }^{[75]}$ This suggests a selectivity for cancer cells which is consistent with our previous observation that $\mathbf{6 b}$ is $100 \mathrm{x}$ less toxic on normal cells than on cancer cells, ${ }^{[81]}$ although it may also be due to a lack of bioavailability. Secondly, incubation of $\mathbf{6 b}$ with nucleotides did not show any direct interaction between the two, as measured by capillary zone electrophoresis (CZE). The low toxicity and lack of reaction with DNA, (though alteration of DNA after metabolism cannot be excluded), suggest that these compounds are only activated in cancer cells to form reactive species.

The COMPARE results suggest interference with DNA as the primary mechanism. These results should be regarded with caution, as mechanisms involving DNA dominate the pool of common anticancer agents. Direct attack on DNA is consistent with our proposed mechanism of quinone methide formation, as quinone methides are known to react with DNA via Michael addition. ${ }^{[82]}$ Indeed, compound $\mathbf{6 b}$ has been shown to damage DNA, but only when incubated in living cells, ${ }^{[83]}$ where it is presumably metabolized to the quinone methide or other active species. However, these results do not exclude the possibility of other targets. For example, 
we have found (unpublished results) that the quinone methide forms of some of these compounds can react with glutathione and other thiols, such as those present in many proteins.

\section{Conclusions}

We have described the synthesis and antiproliferative effects for 11 new compounds based on the 1-(diphenylmethylidene)-[3]ferrocenophane or the 1(diphenylmethylidenyl)ethylferrocene skeletons. Of the full 28-member library, compounds possessing the [3]ferrocenophane motif are, in every case, more active against the MDA-MB231 hormone-independent breast cancer cell line than the corresponding ferrocenyl compounds. This is consistent with the smaller HOMO-LUMO gap present in the oxidized form of the [3]ferrocenophane compounds. Furthermore, those compounds which can form quinone or imine methides (with or without preliminary hydrolysis) are the most active of both the [3]ferrocenophane and ferrocene series. Results on the NCI/DPT 60 cell line panel show greater cell line selectivity for $\mathbf{6 a}$ than for $\mathbf{6 b}$, although the qualitative subpanel selectivity patterns are similar. Possible mechanisms of action, as gleaned from a COMPARE analysis include the compounds acting as DNA alkylating agents or DNA antimetabolites. The low systemic toxicity and inertness with regard to DNA may be due to their putative behavior as oxidation-activated prodrugs.

\section{Experimental Section}

\section{General remarks}

All reactions were performed under argon using standard Schlenk techniques. Anhydrous THF was obtained by distillation from sodium/benzophenone. Thin layer chromatography was performed on silica gel $60 \mathrm{GF}_{254}$. The preparative HPLC separations were performed on a Shimadzu apparatus with a Nucleodur $C_{18}$ column $(l=25 \mathrm{~cm}, \emptyset=3.2 \mathrm{~cm}$, particle size $=10 \mu \mathrm{m})$ using $\mathrm{CH}_{3} \mathrm{CN}$ as an eluent. The analytical HPLC controls were performed on a Shimadzu apparatus with a Nucleodur $\mathrm{C}_{18}$ column (length of $15 \mathrm{~cm}$, diameter of $0.45 \mathrm{~cm}$, and particle size of $5 \mu \mathrm{m}$ ) using $\mathrm{CH}_{3} \mathrm{CN}$ as an eluent. IR spectra were obtained on an IRFT BOMEM Michelson-100 spectrometer equipped with a DTGS detector as a $\mathrm{KBr}$ plate. ${ }^{1} \mathrm{H}$ and ${ }^{13} \mathrm{C}$ NMR spectra were recorded on a $300 \mathrm{MHz}$ Bruker spectrometer. Mass spectrometry was performed with a Nermag R 10-10C spectrometer. Elemental analyses were performed by the 
microanalysis service of CNRS at Gif-sur-Yvette (France). HRMS measurements were performed with an LTQ-Orbitrap XL of Thermo Fischer used in positive mode with an electrospray source.

\section{General synthesis of $7 b, 13 a$, and $14 a$}

Zinc powder was suspended in dry THF at room temperature, and $\mathrm{TiCl}_{4}$ was added slowly via a syringe while stirring. The reaction mixture was held at reflux for $2 \mathrm{~h}$, after which a THF solution containing the appropriate ketones was added, and reflux was continued. The reaction mixture was poured into $\mathrm{H}_{2} \mathrm{O}$, acidified with $\mathrm{HCl}$ until the black precipitate disappeared, and extracted with $\mathrm{CH}_{2} \mathrm{Cl}_{2}$. The organic layer was washed with $\mathrm{H}_{2} \mathrm{O}$, dried over magnesium sulfate, filtered, and concentrated under reduced pressure, and work-up was done as described below.

1-(4-aminophenyl)-1-(4-hydroxyphenyl)-2-ferrocenylbut-1-ene, 7b. Zinc powder (17 g, $260 \mathrm{mmol}), \mathrm{TiCl}_{4}(15.4 \mathrm{~mL}, 140 \mathrm{mmol})$, propionyl ferrocene $(2.58 \mathrm{~g}, 10.67 \mathrm{mmol}), 4-$ hydroxy-4'-nitrobenzophenone $(2.59 \mathrm{~g}, 10.67 \mathrm{mmol})$, and reflux for $4 \mathrm{~h}$. The reaction mixture was separated on a silica gel column with $\mathrm{CH}_{2} \mathrm{Cl}_{2}$ as the eluent. Recrystallization of the crude product as a mixture of $Z$ and $E$ isomers (50:50) from $\mathrm{CH}_{3} \mathrm{CN}$ yielded $\mathbf{7 b}$ as an orange-red solid (2.8 g, 62\%). ${ }^{1} \mathrm{H}$ NMR (300 MHz, [D 6 DMSO): $\delta=0.99$ and $1.02(\mathrm{t}, J=7.4 \mathrm{~Hz}, 3 \mathrm{H}$, $\mathrm{CH}_{3}$ ), 2.50 (q, $J=7.4 \mathrm{~Hz}, 2 \mathrm{H}, \mathrm{CH}_{2}$ ), 3.80 and 3.86 (t, $J=1.8 \mathrm{~Hz}, 2 \mathrm{H}, \mathrm{C}_{5} \mathrm{H}_{4}$ ), 4.07 and 4.08 (t, $\left.J=1.8 \mathrm{~Hz}, 2 \mathrm{H}, \mathrm{C}_{5} \mathrm{H}_{4}\right), 4.09$ and $4.11(\mathrm{~s}, 5 \mathrm{H}, \mathrm{Cp}), 4.99$ and 5.01 (s broad, $2 \mathrm{H}, \mathrm{NH}_{2}$ ), 6.42 and $6.54\left(\mathrm{~d}, J=8.5 \mathrm{~Hz}, 2 \mathrm{H}, \mathrm{C}_{6} \mathrm{H}_{4}\right), 6.64$ and $6.92\left(\mathrm{~d}, J=8.5 \mathrm{~Hz}, 2 \mathrm{H}, \mathrm{C}_{6} \mathrm{H}_{4}\right), 6.71$ and $6.73(\mathrm{~d}, J=8.5$ $\left.\mathrm{Hz}, 2 \mathrm{H}, \mathrm{C}_{6} \mathrm{H}_{4}\right), 6.98$ and $7.01\left(\mathrm{~d}, J=8.5 \mathrm{~Hz}, 2 \mathrm{H}, \mathrm{C}_{6} \mathrm{H}_{4}\right), 9.25$ and 9.31 (s, $\left.1 \mathrm{H}, \mathrm{OH}\right) ;{ }^{13} \mathrm{C} \mathrm{NMR}$ (75.4 MHz, [D $\mathrm{D}_{6}$ DMSO): $\delta=15.4\left(\mathrm{CH}_{3}\right), 27.1\left(\mathrm{CH}_{2}\right), 67.7\left(2 \mathrm{CH} \mathrm{C}_{5} \mathrm{H}_{4}\right), 68.6\left(2 \mathrm{CH} \mathrm{C}_{5} \mathrm{H}_{4}\right), 68.9$ (5CH Cp), $86.1\left(\mathrm{C}_{\mathrm{ip}}\right), 115.1\left(2 \mathrm{CH} \mathrm{C}_{6} \mathrm{H}_{4}\right), 119.2\left(2 \mathrm{CH} \mathrm{C}_{6} \mathrm{H}_{4}\right), 129.7\left(2 \mathrm{CH} \mathrm{C}_{6} \mathrm{H}_{4}\right), 129.8(2 \mathrm{CH}$ $\left.\mathrm{C}_{6} \mathrm{H}_{4}\right), 134.9(\mathrm{C}), 136.0(\mathrm{C}), 137.3(\mathrm{C}), 139.4(\mathrm{C}), 149.2$ (C), $155.6(\mathrm{C})$; IR (KBr, $\left.\breve{v} \mathrm{~cm}^{-1}\right)$ : 3495, 3469, 3428, 3399, $3319\left(\mathrm{OH}, \mathrm{NH}_{2}\right), 3088,2980,2959,2923,2866\left(\mathrm{CH}_{2}, \mathrm{CH}_{3}\right)$; MS $\left(\mathrm{CI}, \mathrm{NH}_{3} \text { ) m/z: } 424 \text { [M+H] }\right]^{+}$; HRMS (EI, $70 \mathrm{eV}, \mathrm{C}_{26} \mathrm{H}_{25} \mathrm{FeNO}:[\mathrm{M}]^{+}$) calcd: 423.1286, found: 423.1299; Anal. calcd for $\mathrm{C}_{26} \mathrm{H}_{25} \mathrm{FeNO} \cdot 0.5 \mathrm{H}_{2} \mathrm{O}: \mathrm{C} 72.23, \mathrm{H} 6.06, \mathrm{~N} 3.24$, found: $\mathrm{C} 72.16, \mathrm{H}$ $5.95, \mathrm{~N} 3.01$.

1-[(4-bromophenyl)phenylmethylidene]-[3]ferrocenophane, 13a. Zinc powder (1.96 g, 30 mmol), $\mathrm{TiCl}_{4}(2.2 \mathrm{~mL}, 20 \mathrm{mmol})$, [3]ferrocenophane-1-one $(1.2 \mathrm{~g}, 5 \mathrm{mmol}), \quad p$ bromobenzophenone $(1.31 \mathrm{~g}, 5 \mathrm{mmol})$, and reflux for $3.5 \mathrm{~h}$. Purification by HPLC with 
$\mathrm{CH}_{3} \mathrm{CN}$ as eluent. Recrystallization from hexane yielded 13a as bright yellow crystals $(2.08 \mathrm{~g}$, $89 \%)$ as an unidentified mixture of $Z$ and $E$ isomers (62:38). ${ }^{1} \mathrm{H}$ NMR (300 $\mathrm{MHz}, \mathrm{CDCl}_{3}$ ): $\delta=2.15\left(\mathrm{~s}, 2 \mathrm{H}, \mathrm{CH}_{2}\right), 2.46\left(\mathrm{~s}, 2 \mathrm{H}, \mathrm{CH}_{2}\right), 3.86\left(\mathrm{~s}, 2 \mathrm{H}, \mathrm{C}_{5} \mathrm{H}_{4}\right), 3.89$ (s, 2H, $\left.\mathrm{C}_{5} \mathrm{H}_{4}\right), 3.94(\mathrm{~s}, 2 \mathrm{H}$, $\left.\mathrm{C}_{5} \mathrm{H}_{4}\right), 4.12$ (s, 2H, $\left.\mathrm{C}_{5} \mathrm{H}_{4}\right), 6.72\left(\mathrm{~d}, J=8.4 \mathrm{~Hz}, 2 \mathrm{H}, \mathrm{C}_{6} \mathrm{H}_{4}\right), 6.79$ (d, J=8.4 Hz, 2H, $\left.\mathrm{C}_{6} \mathrm{H}_{4}\right), 6.88$ $7.33\left(\mathrm{~m}, 5 \mathrm{H}, \mathrm{C}_{6} \mathrm{H}_{5}\right) ;{ }^{13} \mathrm{C} \mathrm{NMR}\left(75.4 \mathrm{MHz}, \mathrm{CDCl}_{3}\right): \delta=28.7\left(\mathrm{CH}_{2}\right), 40.6$ and $40.8\left(\mathrm{CH}_{2}\right), 69.1$ $\left(2 \mathrm{CH} \mathrm{C}_{5} \mathrm{H}_{4}\right), 69.7\left(2 \mathrm{CH} \mathrm{C}_{5} \mathrm{H}_{4}\right), 70.4\left(2 \mathrm{CH} \mathrm{C}_{5} \mathrm{H}_{4}\right), 70.5\left(2 \mathrm{CH} \mathrm{C}_{5} \mathrm{H}_{4}\right), 83.3\left(\mathrm{C}_{\mathrm{ip}}\right), 86.9\left(\mathrm{C}_{\mathrm{ip}}\right)$, 120.1 and $120.7(\mathrm{C}-\mathrm{Br}), 126.3$ and $126.9\left(\mathrm{CH} \mathrm{C}_{6} \mathrm{H}_{5}\right), 127.5$ and $128.3\left(2 \mathrm{CH}_{\text {arom }}\right), 129.3$ and $131.0\left(2 \mathrm{CH}_{\text {arom }}\right), 130.5\left(2 \mathrm{CH}_{\text {arom }}\right), 131.4$ and $132.2\left(2 \mathrm{CH}_{\text {arom }}\right), 135.7(\mathrm{C}), 139.5$ and $139.6(\mathrm{C})$, 142.0 and 142.5 (C), 142.6 and 143.0 (C); IR (KBr, $\left.\bar{v} \mathrm{~cm}^{-1}\right)$ : 3081, 2953, 2920, $2842\left(\mathrm{CH}_{2}\right)$; MS (EI, $70 \mathrm{eV}) \mathrm{m} / z$ : $468[\mathrm{M}]^{+.}\left({ }^{79} \mathrm{Br}\right)$; Anal. calcd for $\mathrm{C}_{26} \mathrm{H}_{21} \mathrm{BrFe}: \mathrm{C} 66.55, \mathrm{H} 4.51$, found: $\mathrm{C}$ $66.35, \mathrm{H} 4.53$.

1-[(di-4-bromophenyl)methylidene]-[3]ferrocenophane, 14a. Zinc powder (1.96 g, 30 mmol), $\mathrm{TiCl}_{4}(2.2 \mathrm{~mL}, 20 \mathrm{mmol})$, [3]ferrocenophane-1-one $(1.2 \mathrm{~g}, 5 \mathrm{mmol})$, di-pbromobenzophenone $(1.7 \mathrm{~g}, 5 \mathrm{mmol})$, and reflux for $3.5 \mathrm{~h}$. Purification by HPLC with $\mathrm{CH}_{3} \mathrm{CN}$ as eluent. Recrystallization from $\mathrm{CH}_{2} \mathrm{Cl}_{2}$ yielded $\mathbf{1 4 a}$ as yellow crystals $(2.21 \mathrm{~g}$, 81\%); mp: $142^{\circ} \mathrm{C} ;{ }^{1} \mathrm{H}$ NMR (300 $\left.\mathrm{MHz}, \mathrm{CDCl}_{3}\right): \delta=2.33\left(\mathrm{~m}, 2 \mathrm{H}, \mathrm{CH}_{2}\right), 2.64\left(\mathrm{~m}, 2 \mathrm{H}, \mathrm{CH}_{2}\right)$, $3.99\left(\mathrm{~s}, 2 \mathrm{H}, \mathrm{C}_{5} \mathrm{H}_{4}\right), 4.02\left(\mathrm{~s}, 2 \mathrm{H}, \mathrm{C}_{5} \mathrm{H}_{4}\right), 4.08\left(\mathrm{~s}, 2 \mathrm{H}, \mathrm{C}_{5} \mathrm{H}_{4}\right), 4.25\left(\mathrm{~s}, 2 \mathrm{H}, \mathrm{C}_{5} \mathrm{H}_{4}\right), 6.90$ (d, J=8.3, $\left.2 \mathrm{H}, \mathrm{C}_{6} \mathrm{H}_{4}\right), 7.09$ (d, J=8.3, 2H, $\left.\mathrm{C}_{6} \mathrm{H}_{4}\right), 7.21$ (d, J=8.3, 2H, $\left.\mathrm{C}_{6} \mathrm{H}_{4}\right), 7.48$ (d, J=8.3, 2H, $\mathrm{C}_{6} \mathrm{H}_{4}$ ); ${ }^{13} \mathrm{C}$ NMR $\left(75.4 \mathrm{MHz}, \mathrm{CDCl}_{3}\right): \delta=28.9\left(\mathrm{CH}_{2}\right), 41.0\left(\mathrm{CH}_{2}\right), 69.0\left(2 \mathrm{CH} \mathrm{C} \mathrm{C}_{5}\right), 69.6(2 \mathrm{CH}$ $\left.\mathrm{C}_{5} \mathrm{H}_{4}\right), 70.4\left(2 \mathrm{CH} \mathrm{C}_{5} \mathrm{H}_{4}\right), 70.6\left(2 \mathrm{CH} \mathrm{C}_{5} \mathrm{H}_{4}\right), 83.0\left(\mathrm{C}_{\mathrm{ip}}\right), 86.7\left(\mathrm{C}_{\mathrm{ip}}\right), 120.5(\mathrm{C}-\mathrm{Br}), 121.1(\mathrm{C}-\mathrm{Br})$, $130.7\left(2 \mathrm{CH} \mathrm{C}_{6} \mathrm{H}_{4}\right), 131.1\left(2 \mathrm{CH} \mathrm{C} \mathrm{H}_{4}\right), 131.6\left(2 \mathrm{CH} \mathrm{C} \mathrm{H}_{4}\right), 132.3\left(2 \mathrm{CH} \mathrm{C}{ }_{6} \mathrm{H}_{4}\right), 136.7(\mathrm{C})$, 138.6 (C), 141.6 (C), 142.0 (C); IR (KBr, $\left.\bar{v} \mathrm{~cm}^{-1}\right)$ : 2923, $2843\left(\mathrm{CH}_{2}\right)$; MS (EI, $\left.70 \mathrm{eV}\right) \mathrm{m} / z: 546$ $[\mathrm{M}]^{+}$; Anal. calcd for $\mathrm{C}_{26} \mathrm{H}_{20} \mathrm{Br}_{2} \mathrm{Fe}$ : C 56.97, H 3.67, found: C 56.99, H 3.67.

\section{General synthesis of 15a, 16a, 17a}

In a Schlenk tube 13a or 14a were dissolved in anhydrous DMF. Copper(I) cyanide, dissolved in anhydrous DMF, was added dropwise and the reaction mixture was held at reflux for $12 \mathrm{~h}$. The mixture was poured in $10 \mathrm{~mL}$ of a $10 \% \mathrm{NaCN}$ solution and was extracted with $\mathrm{Et}_{2} \mathrm{O}(10$ $\mathrm{mL}$ ). The organic phase was washed with $20 \mathrm{~mL}$ of a $10 \% \mathrm{NaCN}$ solution, followed by 20 $\mathrm{mL}$ of saturated $\mathrm{NaCl}$ solution. The solution was dried over magnesium sulfate, filtered, and concentrated under reduced pressure. After being passed through a small filter (filled to $3 \mathrm{~cm}$ with silica gel) by using a 4:1 solution of petroleum ether and $\mathrm{CH}_{2} \mathrm{Cl}_{2}$, the solvent was 
evaporated. The desired compounds were purified with HPLC with $\mathrm{CH}_{3} \mathrm{CN}$ as eluent, and recrystallization was performed using the appropriate solvent system as described below.

1-[(4-cyanophenyl)phenylmethylidene]-[3]ferrocenophane, 15a. 13a (0.25 g, $0.53 \mathrm{mmol})$, anhydrous DMF (15 mL), copper(I) cyanide (0.286 g, $3.2 \mathrm{mmol})$, anhydrous DMF (12 mL), recrystallization from $\mathrm{CH}_{2} \mathrm{Cl}_{2}$-hexane solvent system. Orange crystals, 15a $(0.162 \mathrm{~g}, 74 \%)$ as an unidentified mixture of $Z$ and $E$ isomers (61:39). ${ }^{1} \mathrm{H}$ NMR (300 MHz, [D 6 acetone): $\delta=2.40-2.46\left(\mathrm{~m}, 2 \mathrm{H}, \mathrm{CH}_{2}\right), 2.70-2.73\left(\mathrm{~m}, 2 \mathrm{H}, \mathrm{CH}_{2}\right), 3.96-3.98\left(\mathrm{~m}, 2 \mathrm{H}, \mathrm{C}_{5} \mathrm{H}_{4}\right), 4.01-4.07(\mathrm{~m}$, $\left.4 \mathrm{H}, \mathrm{C}_{5} \mathrm{H}_{4}\right), 4.32-4.34\left(\mathrm{~m}, 2 \mathrm{H}, \mathrm{C}_{5} \mathrm{H}_{4}\right), 7.04-7.80\left(\mathrm{~m}, 9 \mathrm{H}, \mathrm{C}_{6} \mathrm{H}_{4}\right.$ and $\left.\mathrm{C}_{6} \mathrm{H}_{5}\right) ;{ }^{13} \mathrm{C}$ NMR (75.4 $\mathrm{MHz},\left[\mathrm{D}_{6}\right.$ ]acetone $): \delta=29.3\left(\mathrm{CH}_{2}\right), 41.1$ and $41.5\left(\mathrm{CH}_{2}\right), 69.2\left(2 \mathrm{CH} \mathrm{C} \mathrm{C}_{5}\right), 69.6$ and 69.9 $\left(2 \mathrm{CH} \mathrm{C}_{5} \mathrm{H}_{4}\right), 71.0$ and $71.1\left(2 \mathrm{CH} \mathrm{C}_{5} \mathrm{H}_{4}\right), 71.2\left(2 \mathrm{CH} \mathrm{C}_{5} \mathrm{H}_{4}\right), 83.4$ and $83.6\left(\mathrm{C}_{\mathrm{ip}}\right), 87.3$ and 87.7 $\left(\mathrm{C}_{\mathrm{ip}}\right), 110.3(\mathrm{C}), 119.5(\mathrm{C}), 127.3$ and $128.0\left(\mathrm{CH} \mathrm{C}_{6} \mathrm{H}_{5}\right), 128.5-129.4\left(2 \mathrm{CH}_{\text {arom }}\right), 130.1$ and $131.1\left(2 \mathrm{CH}_{\text {arom }}\right), 131.2$ and $132.0\left(2 \mathrm{CH}_{\text {arom }}\right), 132.1$ and $133.0\left(2 \mathrm{CH}_{\text {arom }}\right), 138.2$ and $139.0(\mathrm{C})$, 140.2 and 140.3 (C), 143.3 and $143.4(\mathrm{C}), 149.1$ and $149.4(\mathrm{C})$; IR ( $\left.\mathrm{KBr}, \bar{v} \mathrm{~cm}^{-1}\right): 3080,2954$, 2923, $2852\left(\mathrm{CH}_{2}\right), 2226(\mathrm{CN})$; MS (EI, $\left.70 \mathrm{eV}\right) \mathrm{m} / z: 415[\mathrm{M}]^{+.}, 336,121$; Anal. calcd for $\mathrm{C}_{27} \mathrm{H}_{21} \mathrm{FeN}$ : C 78.08, H 5.09, N 3.37, found: C 77.69, H 5.02, N 3.29.

1-[(di-4-cyanophenyl)methylidene]-[3]ferrocenophane, 16a and 1-[(4-bromophenyl)-(4cyanophenyl)methylidene]-[3]ferrocenophane, 17a. 14a (1.7 g, $3.1 \mathrm{mmol})$, anhydrous DMF (15 mL), copper(I) cyanide (3.33 g, $37.2 \mathrm{mmol})$, anhydrous DMF (12 mL). Recrystallization from $\mathrm{CH}_{2} \mathrm{Cl}_{2}$ gave orange crystals of $\mathbf{1 6 a}(0.6 \mathrm{~g}, 44 \%)$ and orange crystals of $\mathbf{1 7} \mathbf{a}(0.22 \mathrm{~g}, 15 \%)$ as an unidentified mixture of $Z$ and $E$ isomers (56:44).

16a; mp: $190^{\circ} \mathrm{C} .{ }^{1} \mathrm{H}$ NMR (300 MHz, [D $\left.\mathrm{D}_{6}\right]$ acetone): $\delta=2.45\left(\mathrm{~m}, 2 \mathrm{H}, \mathrm{CH}_{2}\right), 2.74\left(\mathrm{~m}, 2 \mathrm{H}, \mathrm{CH}_{2}\right)$, $3.96\left(\mathrm{t}, J=1.8,2 \mathrm{H}, \mathrm{C}_{5} \mathrm{H}_{4}\right), 4.05\left(\mathrm{t}, J=1.8,2 \mathrm{H}, \mathrm{C}_{5} \mathrm{H}_{4}\right), 4.08\left(\mathrm{t}, J=1.8,2 \mathrm{H}, \mathrm{C}_{5} \mathrm{H}_{4}\right), 4.35(\mathrm{t}, J=1.8$, $\left.2 \mathrm{H}, \mathrm{C}_{5} \mathrm{H}_{4}\right), 7.24\left(\mathrm{~d}, J=8.5,2 \mathrm{H}, \mathrm{C}_{6} \mathrm{H}_{4}\right), 7.52$ (d, J=8.5, 4H, $\left.\mathrm{C}_{6} \mathrm{H}_{4}\right), 7.82\left(\mathrm{~d}, J=8.5,2 \mathrm{H}, \mathrm{C}_{6} \mathrm{H}_{4}\right)$; ${ }^{13} \mathrm{C}$ NMR (75.4 MHz, [D $\mathrm{D}_{6}$ ]acetone): $\delta=29.3\left(\mathrm{CH}_{2}\right), 41.3\left(\mathrm{CH}_{2}\right), 69.3\left(2 \mathrm{CH} \mathrm{C} \mathrm{H}_{4}\right), 70.0(2 \mathrm{CH}$ $\left.\mathrm{C}_{5} \mathrm{H}_{4}\right), 71.1\left(2 \mathrm{CH} \mathrm{C} \mathrm{H}_{4}\right), 71.3\left(2 \mathrm{CH} \mathrm{C}_{5} \mathrm{H}_{4}\right), 82.9\left(\mathrm{C}_{\mathrm{ip}}\right), 87.4\left(\mathrm{C}_{\mathrm{ip}}\right), 110.1(2 \mathrm{C}), 119.3(2 \mathrm{C})$, $131.3\left(2 \mathrm{CH} \mathrm{C}_{6} \mathrm{H}_{4}\right), 132.2\left(2 \mathrm{CH} \mathrm{C}_{6} \mathrm{H}_{4}\right), 132.3\left(2 \mathrm{CH} \mathrm{C} \mathrm{H}_{4}\right), 133.3\left(2 \mathrm{CH} \mathrm{C}_{6} \mathrm{H}_{4}\right), 138.7(\mathrm{C})$, 141.1 (C), 148.2 (2C); IR (KBr, $\left.\bar{v} \mathrm{~cm}^{-1}\right): 2948,2922,2848\left(\mathrm{CH}_{2}\right), 2222(\mathrm{CN})$; MS (EI, $\left.70 \mathrm{eV}\right)$ $m / z: 440[\mathrm{M}]^{+.}, 361,278,199,134,121$; HRMS (ESI, $\mathrm{C}_{28} \mathrm{H}_{20} \mathrm{FeN}_{2}$ : [M] ${ }^{+}$) calcd: 440.09704, found: 440.09657; Anal. Calcd for $\mathrm{C}_{28} \mathrm{H}_{20} \mathrm{FeN}_{2} \cdot 0.05 \mathrm{H}_{2} \mathrm{O}: \mathrm{C} 76.22, \mathrm{H} 4.59$, N 6.35, found: C 75.95, H 4.74, N 6.17. 
17a. ${ }^{1} \mathrm{H}$ NMR (300 MHz, $\left[\mathrm{D}_{6}\right]$ acetone): $\delta=2.40-2.45\left(\mathrm{~m}, 2 \mathrm{H}, \mathrm{CH}_{2}\right), 2.68-2.76\left(\mathrm{~m}, 2 \mathrm{H}, \mathrm{CH}_{2}\right)$, $3.96\left(\mathrm{~s}, 2 \mathrm{H}, \mathrm{C}_{5} \mathrm{H}_{4}\right), 4.03-4.09\left(\mathrm{~m}, 4 \mathrm{H}, \mathrm{C}_{5} \mathrm{H}_{4}\right), 4.33\left(\mathrm{~s}, 2 \mathrm{H}, \mathrm{C}_{5} \mathrm{H}_{4}\right), 6.98$ and 7.23 (d, J=8.5, 2H, $\left.\mathrm{C}_{6} \mathrm{H}_{4}\right), 7.25$ and $7.29\left(\mathrm{~d}, J=8.5,2 \mathrm{H}, \mathrm{C}_{6} \mathrm{H}_{4}\right), 7.49$ and $7.50\left(\mathrm{~d}, J=8.5,2 \mathrm{H}, \mathrm{C}_{6} \mathrm{H}_{4}\right), 7.59$ and 7.80 (d, J=8.5, 2H, $\left.\mathrm{C}_{6} \mathrm{H}_{4}\right) ;{ }^{13} \mathrm{C}$ NMR (75.4 MHz, [D $]$ ]acetone): $\delta=29.2\left(\mathrm{CH}_{2}\right), 41.5\left(\mathrm{CH}_{2}\right), 69.2$ $\left(2 \mathrm{CH} \mathrm{C}_{5} \mathrm{H}_{4}\right), 69.8$ and $69.9\left(2 \mathrm{CH} \mathrm{C}_{5} \mathrm{H}_{4}\right), 71.0\left(2 \mathrm{CH}, \mathrm{C}_{5} \mathrm{H}_{4}\right), 71.2\left(2 \mathrm{CH} \mathrm{C}_{5} \mathrm{H}_{4}\right), 83.3\left(\mathrm{C}_{\mathrm{ip}}\right), 87.3$ and $87.6\left(\mathrm{C}_{\mathrm{ip}}\right), 110.5(\mathrm{C}), 119.3(\mathrm{C}), 120.9(\mathrm{C}), 131.2$ and $131.5\left(2 \mathrm{CH} \mathrm{C}{ }_{6} \mathrm{H}_{4}\right), 132.1(2 \mathrm{CH}$ $\left.\mathrm{C}_{6} \mathrm{H}_{4}\right), 132.2$ and $132.5\left(2 \mathrm{CH} \mathrm{C}_{6} \mathrm{H}_{4}\right), 133.1$ and $133.2\left(2 \mathrm{CH} \mathrm{C}_{6} \mathrm{H}_{4}\right), 139.0(\mathrm{C}), 139.3$ and 140.0 (C), 142.5 (C), $148.8(\mathrm{C})$; IR (KBr, $\left.\bar{v} \mathrm{~cm}^{-1}\right)$ : 3066, 2955, 2917, 2902, $2842\left(\mathrm{CH}_{2}\right), 2232(\mathrm{CN})$; HRMS (ESI, $\mathrm{C}_{27} \mathrm{H}_{20} \mathrm{BrFeN}$ : $[\mathrm{M}]^{+}$) calcd: 493.01231, found: 493.01266; Anal. calcd for $\mathrm{C}_{27} \mathrm{H}_{21} \mathrm{FeNBr} \cdot 0.26 \mathrm{H}_{2} \mathrm{O}: \mathrm{C}$ 65.00, H 4.15, N 2.81, found: C 64.91, H 4.44, N 2.53.

\section{General synthesis of 11a and 12a}

In a Schlenk flask, 6a (0.84 g, 2 mmol) was dissolved in anhydrous THF and NaH (0.12 g, 5 mmol, $60 \%$ suspension in oil) was added. After 10 min stirring, acetyl chloride $(0.3 \mathrm{~mL}, 4.2$ mmol) was added and the reaction mixture was stirred for $3 \mathrm{~h}$. The mixture was poured in $\mathrm{H}_{2} \mathrm{O}$, extracted twice with $\mathrm{CH}_{2} \mathrm{Cl}_{2}$, and concentrated under reduced pressure. Products were separated by HPLC with a solution $90: 10$ of $\mathrm{CH}_{3} \mathrm{CN} / \mathrm{H}_{2} \mathrm{O}$ as the eluent to yield the mono- and diacetylated products. Then the products were recrystallized from EtOH to yield bright yellow crystals of 11a $(0.43 \mathrm{~g}, 46 \%)$ consisting of an unidentified mixture of $Z$ and $E$ isomers (54:46) and bright yellow crystals of $\mathbf{1 2 a}(0.33 \mathrm{~g}, 33 \%)$.

1-[(4-acetyloxyphenyl)-(4-hydroxyphenyl)methylidene]-[3]ferrocenophane, 11a. ${ }^{1} \mathrm{H}$ NMR (300 MHz, [D $\mathrm{D}_{6}$ ]acetone): $\delta=2.18$ and $2.27\left(\mathrm{~s}, 3 \mathrm{H}, \mathrm{CH}_{3}\right), 2.30-2.40\left(\mathrm{~m}, 2 \mathrm{H}, \mathrm{CH}_{2}\right), 2.62-2.74$ (m, 2H, $\mathrm{CH}_{2}$ ), 3.94 (t, J=1.7, 2H, $\left.\mathrm{C}_{5} \mathrm{H}_{4}\right), 3.96-4.05$ (m, 4H, $\left.\mathrm{C}_{5} \mathrm{H}_{4}\right), 4.27$ (t, J=1.7, 2H, $\mathrm{C}_{5} \mathrm{H}_{4}$ ), 6.56 and $6.83\left(\mathrm{~d}, J=8.8,2 \mathrm{H}, \mathrm{C}_{6} \mathrm{H}_{4}\right), 6.86$ and $7.04\left(\mathrm{~d}, J=8.8,2 \mathrm{H}, \mathrm{C}_{6} \mathrm{H}_{4}\right), 6.87$ and $7.09(\mathrm{~d}$, $\left.J=8.8,2 \mathrm{H}, \mathrm{C}_{6} \mathrm{H}_{4}\right), 7.13$ and $7.28\left(\mathrm{~d}, J=8.8,2 \mathrm{H}, \mathrm{C}_{6} \mathrm{H}_{4}\right), 8.18$ and $8.38(\mathrm{~s}, 1 \mathrm{H}, \mathrm{OH}) ;{ }^{13} \mathrm{C} \mathrm{NMR}$ (75.4 MHz, [D ]acetone): $21.0\left(\mathrm{CH}_{3}\right), 29.2\left(\mathrm{CH}_{2}\right), 41.3$ and $41.6\left(\mathrm{CH}_{2}\right), 68.9\left(2 \mathrm{CH} \mathrm{C}_{5} \mathrm{H}_{4}\right)$, 69.3 and $69.4\left(2 \mathrm{CH} \mathrm{C}_{5} \mathrm{H}_{4}\right), 70.9\left(2 \mathrm{CH} \mathrm{C}_{5} \mathrm{H}_{4}\right), 71.1\left(2 \mathrm{CH} \mathrm{C}_{5} \mathrm{H}_{4}\right), 84.4$ and $84.5\left(\mathrm{C}_{\mathrm{ip}}\right), 87.5$ and $87.8\left(\mathrm{C}_{\mathrm{ip}}\right), 115.1$ and $115.9\left(2 \mathrm{CH} \mathrm{C}_{6} \mathrm{H}_{4}\right), 121.3$ and $122.3\left(2 \mathrm{CH} \mathrm{C}_{6} \mathrm{H}_{4}\right), 130.9$ and $131.2(2 \mathrm{CH}$ $\left.\mathrm{C}_{6} \mathrm{H}_{4}\right), 132.1$ and $132.4\left(2 \mathrm{CH} \mathrm{C}_{6} \mathrm{H}_{4}\right), 134.8$ and $135.3(\mathrm{C}), 135.5(\mathrm{C}), 140.8$ and $140.9(\mathrm{C})$, 142.0 and $142.3(\mathrm{C}), 150.0$ and $150.6(\mathrm{C}), 156.7$ and 157.3 (C), 169.4 and 169.6 (CO); IR $\left(\mathrm{KBr}, \bar{v} \mathrm{~cm}^{-1}\right): 3434(\mathrm{OH}), 3077,2915,2853\left(\mathrm{CH}_{3}, \mathrm{CH}_{2}\right), 1731(\mathrm{CO})$; MS (EI, $\left.70 \mathrm{eV}\right) \mathrm{m} / \mathrm{z}$ : 
$464[\mathrm{M}]^{+}$, 422, 343; HRMS (ESI, $\mathrm{C}_{28} \mathrm{H}_{24} \mathrm{FeO}_{3}$ : $[\mathrm{M}]^{+}$) calcd: 464.1076, found: 464.10694; Anal. Calcd for $\mathrm{C}_{28} \mathrm{H}_{24} \mathrm{FeO}_{3} \cdot 0.54 \mathrm{H}_{2} \mathrm{O}: \mathrm{C} 70.94$, H 5.33, found: $\mathrm{C} 70.66, \mathrm{H}$ 5.42.

1-[(di-4-acetyloxyphenyl)methylidene]-[3]ferrocenophane, 12a; mp: $192^{\circ} \mathrm{C}$ (dec.) ${ }^{1} \mathrm{H}$ NMR (300 MHz, $\left.\mathrm{CDCl}_{3}\right): \delta=2.23\left(\mathrm{~s}, 3 \mathrm{H}, \mathrm{CH}_{3}\right), 2.31\left(\mathrm{~s}, 3 \mathrm{H}, \mathrm{CH}_{3}\right), 2.36\left(\mathrm{~m}, 2 \mathrm{H}, \mathrm{CH}_{2}\right), 2.68$ (m, 2H, $\left.\mathrm{CH}_{2}\right), 3.97\left(\mathrm{~s}, 4 \mathrm{H}, \mathrm{C}_{5} \mathrm{H}_{4}\right), 4.03\left(\mathrm{~s}, 2 \mathrm{H}, \mathrm{C}_{5} \mathrm{H}_{4}\right), 4.22\left(\mathrm{~s}, 2 \mathrm{H}, \mathrm{C}_{5} \mathrm{H}_{4}\right), 6.81$ (d, J=8.7, 2H, $\left.\mathrm{C}_{6} \mathrm{H}_{4}\right), 7.03\left(\mathrm{~d}, J=8.7,2 \mathrm{H}, \mathrm{C}_{6} \mathrm{H}_{4}\right), 7.07$ (d, $\left.J=8.4,2 \mathrm{H}, \mathrm{C}_{6} \mathrm{H}_{4}\right), 7.24\left(\mathrm{~d}, J=8.4,2 \mathrm{H}, \mathrm{C}_{6} \mathrm{H}_{4}\right) ;{ }^{13} \mathrm{C}$ NMR (75.4 MHz, $\left.\mathrm{CDCl}_{3}\right): \delta=21.3\left(2 \mathrm{CH}_{3}\right), 28.9\left(\mathrm{CH}_{2}\right), 41.1\left(\mathrm{CH}_{2}\right), 68.5\left(2 \mathrm{CH} \mathrm{C}_{5} \mathrm{H}_{4}\right), 69.1$ $\left(2 \mathrm{CH} \mathrm{C}_{5} \mathrm{H}_{4}\right), 70.3\left(2 \mathrm{CH} \mathrm{C}_{5} \mathrm{H}_{4}\right), 70.4\left(2 \mathrm{CH} \mathrm{C}_{5} \mathrm{H}_{4}\right), 83.3\left(\mathrm{C}_{\mathrm{ip}}\right), 86.7\left(\mathrm{C}_{\mathrm{ip}}\right), 120.4\left(2 \mathrm{CH} \mathrm{C}_{6} \mathrm{H}_{4}\right)$, $121.4\left(2 \mathrm{CH} \mathrm{C}_{6} \mathrm{H}_{4}\right), 130.5\left(2 \mathrm{CH} \mathrm{C}_{6} \mathrm{H}_{4}\right), 131.7\left(2 \mathrm{CH} \mathrm{C}_{6} \mathrm{H}_{4}\right), 136.0(\mathrm{C}), 139.3(\mathrm{C}), 140.5$ (C), 140.9 (C), 149.0 (C), 149.6 (C), 169.4 (2CO); IR (KBr, $\left.\bar{v} \mathrm{~cm}^{-1}\right): 3089,3047,2942,2850\left(\mathrm{CH}_{3}\right.$, $\mathrm{CH}_{2}$ ), 1755 (CO); MS (EI, $70 \mathrm{eV}$ ) m/z: $506[\mathrm{M}]^{+}$, 464, 343; Anal. calcd for $\mathrm{C}_{30} \mathrm{H}_{26} \mathrm{FeO}_{4}$ : C 71.15, H 5.17, found: C 70.95, H 5.25.

1-(4-acetoxyphenyl)-1-(4-hydroxyphenyl)-2-ferrocenylbut-1-ene, 11b. The same procedure as for synthesis of 11a and 12a was used with $\mathbf{6 b}(0.84 \mathrm{~g}, 2 \mathrm{mmol}), \mathrm{NaH}(0.12 \mathrm{~g}, 5$ mmol, 60\% suspension in oil), and acetyl chloride $(0.2 \mathrm{~mL}, 2.4 \mathrm{mmol})$ to yield $\mathbf{1 1 b}(0.60 \mathrm{~g}$, $65 \%$ ) as an orange solid consisting of an unidentified mixture of $Z$ and $E$ isomers (50:50). ${ }^{1} \mathrm{H}$ NMR $\left(\mathrm{CDCl}_{3}\right): \delta=0.92\left(\mathrm{t}, J=6.8 \mathrm{~Hz}, 3 \mathrm{H}, \mathrm{CH}_{3}\right), 2.20$ and $2.23\left(\mathrm{~s}, 3 \mathrm{H}, \mathrm{CH}_{3}\right), 2.31-2.51(\mathrm{~m}, 2 \mathrm{H}$, $\mathrm{CH}_{2}$ ), 3.92 and $3.95\left(\mathrm{~s}, 2 \mathrm{H}, \mathrm{C}_{5} \mathrm{H}_{4}\right), 4.02-4.19\left(\mathrm{~m}, 7 \mathrm{H}, \mathrm{C}_{5} \mathrm{H}_{4}+\mathrm{Cp}\right), 4.72$ and $4.77(\mathrm{~s}, 1 \mathrm{H}, \mathrm{OH})$, 6.62 and $6.71\left(\mathrm{~d}, J=7.9 \mathrm{~Hz}, 2 \mathrm{H}, \mathrm{C}_{6} \mathrm{H}_{4}\right), 6.86\left(\mathrm{~d}, J=8.5 \mathrm{~Hz}, 2 \mathrm{H}, \mathrm{C}_{6} \mathrm{H}_{4}\right), 6.92-7.14(\mathrm{~m}, 4 \mathrm{H}$, $\left.\mathrm{C}_{6} \mathrm{H}_{4}\right) ;{ }^{13} \mathrm{C} \mathrm{NMR}\left(\mathrm{CDCl}_{3}\right): \delta=15.4$ and $15.5\left(\mathrm{CH}_{3}\right), 21.2\left(\mathrm{CH}_{3}\right), 27.9$ and $28.1\left(\mathrm{CH}_{2}\right), 68.9$ and $69.0\left(2 \mathrm{CH}, \mathrm{C}_{5} \mathrm{H}_{4}\right), 69.7$ and $69.8\left(2 \mathrm{CH} \mathrm{C}_{5} \mathrm{H}_{4}\right), 70.0$ and $70.2(5 \mathrm{CH} \mathrm{Cp}), 86.9\left(\mathrm{C}_{\mathrm{ip}}\right), 115.1$ and $115.2\left(2 \mathrm{CH} \mathrm{C}_{6} \mathrm{H}_{4}\right), 121.1$ and $121.2\left(2 \mathrm{CH} \mathrm{C}_{6} \mathrm{H}_{4}\right), 130.4$ and $130.8\left(2 \mathrm{CH} \mathrm{C}_{6} \mathrm{H}_{4}\right), 131.1$ and $131.4\left(2 \mathrm{CH} \mathrm{C}_{6} \mathrm{H}_{4}\right), 136.6$ and $136.9(\mathrm{C}), 136.9$ and $137.4(\mathrm{C}), 138.5$ and $138.9(\mathrm{C}), 142.0$ and $142.3(\mathrm{C}), 148.9$ (C), 154.0 and 154.1 (C), 169.5 and $169.6(\mathrm{CO}) . \mathrm{R}\left(\mathrm{KBr}, \bar{v} \mathrm{~cm}^{-1}\right): 3367$ (OH), 3093, 3035, 2966, 2931, $2870\left(\mathrm{CH}_{2}, \mathrm{CH}_{3}\right), 1728(\mathrm{CO})$; MS (CI, CH 4$) m / z: 467[\mathrm{M}+\mathrm{H}]^{+}$, $495\left[\mathrm{M}+\mathrm{C}_{2} \mathrm{H}_{5}\right]^{+}$, 401; Anal. calcd for $\mathrm{C}_{28} \mathrm{H}_{26} \mathrm{FeO}_{3}: \mathrm{C}, 72.11 ; \mathrm{H}, 5.61$, found: $\mathrm{C}, 72.11 ; \mathrm{H}$, 5.67 .

1-[(4-acetyloxyphenyl)(phenyl)methylidene]-[3]ferrocenophane, 3a. The same procedure as for the synthesis of $\mathbf{1 1 a}$ and $\mathbf{1 2 a}$ was used with $\mathbf{2 a}(0.251 \mathrm{~g}, 0.62 \mathrm{mmol}), \mathrm{NaH}(0.05 \mathrm{~g}, 1.24$ mmol, 60\% suspension in oil), and acetyl chloride $(0.065 \mathrm{~mL}, 0.91 \mathrm{mmol})$. After concentration under reduced pressure, the crude product was directly purified by preparative 
HPLC with an $\mathrm{CH}_{3} \mathrm{CN} / \mathrm{H}_{2} \mathrm{O}$ (95:5) solution as the eluent (because of decomposition on silica gel) to give 3a $(0.183 \mathrm{~g}, 66 \%$ yield $)$ as a light yellow solid consisting of an unidentified mixture of $Z$ and $E$ isomers (82:18). ${ }^{1} \mathrm{H}$ NMR (300 MHz, $\left.\mathrm{CDCl}_{3}\right): \delta=2.15$ (s, 3H, $\mathrm{CH}_{3}$ ), 2.16$2.26\left(\mathrm{~m}, 2 \mathrm{H}, \mathrm{CH}_{2}\right), 2.47-2.59\left(\mathrm{~m}, 2 \mathrm{H}, \mathrm{CH}_{2}\right), 3.95$ (s broad, $\left.2 \mathrm{H}, \mathrm{C}_{5} \mathrm{H}_{4}\right), 3.97$ (s broad, $2 \mathrm{H}$, $\left.\mathrm{C}_{5} \mathrm{H}_{4}\right), 4.03\left(\mathrm{~s}, 2 \mathrm{H}, \mathrm{C}_{5} \mathrm{H}_{4}\right), 4.20\left(\mathrm{~s}, 2 \mathrm{H}, \mathrm{C}_{5} \mathrm{H}_{4}\right), 6.75$ (d, J=8.4 Hz, 2H, $\left.\mathrm{C}_{6} \mathrm{H}_{4}\right), 6.99$ (d, J=8.4 $\left.\mathrm{Hz}, 2 \mathrm{H}, \mathrm{C}_{6} \mathrm{H}_{4}\right), 7.11-7.31\left(\mathrm{~m}, 5 \mathrm{H}, \mathrm{C}_{6} \mathrm{H}_{5}\right) ;{ }^{13} \mathrm{C} \mathrm{NMR}\left(75.4 \mathrm{MHz}, \mathrm{CDCl}_{3}\right): \delta=21.2\left(\mathrm{CH}_{3}\right), 26.5$ and $28.7\left(\mathrm{CH}_{2}\right), 40.7\left(\mathrm{CH}_{2}\right), 69.3\left(2 \mathrm{CH} \mathrm{C}_{5} \mathrm{H}_{4}\right), 69.9\left(2 \mathrm{CH} \mathrm{C}_{5} \mathrm{H}_{4}\right), 70.5\left(2 \mathrm{CH} \mathrm{C}_{5} \mathrm{H}_{4}\right), 70.6(2 \mathrm{CH}$ $\left.\mathrm{C}_{5} \mathrm{H}_{4}\right), 83.5\left(\mathrm{C}_{\mathrm{ip}}\right), 87.0\left(\mathrm{C}_{\mathrm{ip}}\right), 120.3$ and $121.2\left(2 \mathrm{CH} \mathrm{C}_{6} \mathrm{H}_{4}\right), 126.2$ and $126.8\left(\mathrm{CH} \mathrm{C}_{6} \mathrm{H}_{5}\right), 127.4$ and $128.2\left(2 \mathrm{CH}_{\text {arom }}\right), 129.3$ and $130.3\left(2 \mathrm{CH}_{\text {arom }}\right), 130.5$ and $131.5\left(2 \mathrm{CH}_{\text {arom }}\right), 135.3(\mathrm{C}), 139.8$ (C), 140.5 (C), 143.3 (C), 148.8 (C), 169.2 (CO); IR (KBr, $\left.\bar{v} \mathrm{~cm}^{-1}\right)$ : 1762 (CO), 1501, 1206; HRMS (ESI, $\mathrm{C}_{28} \mathrm{H}_{24} \mathrm{FeO}_{2}$ : [M] ${ }^{+}$): calcd: 448.11202, found: 448.11206.

1-(4-acetyloxyphenyl)-1-phenyl-2-ferrocenylbut-1-ene, 3b. The same procedure as for synthesis of 11a and 12a was used with $2 \mathbf{b}$ (0.5 g, $1.23 \mathrm{mmol}), \mathrm{NaH}$ (0.098 g, $2.46 \mathrm{mmol}$, $60 \%$ suspension in oil), and acetyl chloride $(0.13 \mathrm{~mL}, 1.8 \mathrm{mmol})$. After concentration under reduced pressure, the crude product was directly purified by preparative HPLC with an $\mathrm{CH}_{3} \mathrm{CN} / \mathrm{H}_{2} \mathrm{O}$ (95:5) solution as the eluent (because of decomposition on silica gel) to give $\mathbf{3 b}$ ( $0.26 \mathrm{~g}, 47 \%$ yield) a dark red oil consisting of an unidentified mixture of $Z$ and $E$ isomers (54:46). ${ }^{1} \mathrm{H}$ NMR (300 MHz, $\mathrm{CDCl}_{3}$ ): $\delta=0.90$ and $0.93\left(\mathrm{t}, J=7.2 \mathrm{~Hz}, 3 \mathrm{H}, \mathrm{CH}_{3}\right.$ ), 2.16 and 2.19 (s, 3H, $\mathrm{CH}_{3}$ ), 2.37 and 2.38 (q, J=7.2 Hz, 2H, $\mathrm{CH}_{2}$ ), $3.90\left(\mathrm{~s}, 2 \mathrm{H}, \mathrm{C}_{5} \mathrm{H}_{4}\right), 4.08(\mathrm{~s}, 7 \mathrm{H}$, $\left.\mathrm{C}_{5} \mathrm{H}_{4}+\mathrm{Cp}\right), 6.85$ and $6.95\left(\mathrm{~d}, J=8.3 \mathrm{~Hz}, 2 \mathrm{H}, \mathrm{C}_{6} \mathrm{H}_{4}\right), 6.98\left(\mathrm{~d}, J=8.3 \mathrm{~Hz}, 2 \mathrm{H}, \mathrm{C}_{6} \mathrm{H}_{4}\right), 7.03-7.25$ $\left(\mathrm{m}, 5 \mathrm{H}, \mathrm{C}_{6} \mathrm{H}_{5}\right) ;{ }^{13} \mathrm{C} \mathrm{NMR}\left(75.4 \mathrm{MHz}, \mathrm{CDCl}_{3}\right): \delta=15.4$ and $15.5\left(\mathrm{CH}_{3}\right), 21.2\left(\mathrm{CH}_{3}\right), 27.8$ and $28.1\left(\mathrm{CH}_{2}\right), 68.9\left(2 \mathrm{CH} \mathrm{C}_{5} \mathrm{H}_{4}\right), 69.7$ and $69.9(5 \mathrm{CH} \mathrm{Cp}), 70.0\left(2 \mathrm{CH} \mathrm{C}_{5} \mathrm{H}_{4}\right), 87.5\left(\mathrm{C}_{\mathrm{ip}}\right), 121.2$ and $121.3\left(2 \mathrm{CH} \mathrm{C}_{6} \mathrm{H}_{4}\right), 126.3\left(\mathrm{CH} \mathrm{C}_{6} \mathrm{H}_{5}\right), 128.2$ and $128.3\left(2 \mathrm{CH}_{\text {arom }}\right), 129.5$ and 130.0 $\left(2 \mathrm{CH}_{\text {arom }}\right), 130.3$ and $140.0\left(2 \mathrm{CH}_{\text {arom }}\right), 137.2(\mathrm{C}), 137.9(\mathrm{C}), 141.8$ and $142.0(\mathrm{C}), 144.1$ and 144.3 (C), 149.0 (C), 169.3 and 169.4 (CO); IR (KBr, $\left.\bar{v} \mathrm{~cm}^{-1}\right)$ : 1757 (CO), 1496, 1193; HRMS (ESI, $\mathrm{C}_{28} \mathrm{H}_{26} \mathrm{FeO}_{2}$ : [M] ${ }^{+\cdot}$ ): calcd: 450.12767 , found: 450.12779 .

1-(4- $N$-acetamidophenyl)-1-(4-hydroxyphenyl)-2-ferrocenylbut-1-ene, 8b. In a flask 7b (0.67 g, $1.59 \mathrm{mmol})$ was dissolved in $20 \mathrm{~mL}$ of anhydrous THF. Acetyl chloride $(0.249 \mathrm{~g}$, $0.23 \mathrm{~mL}, 3.2 \mathrm{mmol})$ and pyridine $(0.251 \mathrm{~g}, 0.26 \mathrm{~mL}, 3.2 \mathrm{mmol})$ were added and the reaction mixture was left to stir for $3 \mathrm{~h}$. The mixture was poured into $\mathrm{H}_{2} \mathrm{O}$ and extracted with $\mathrm{CH}_{2} \mathrm{Cl}_{2}$. The organic phase was washed with $\mathrm{H}_{2} \mathrm{O}$, dried over magnesium sulfate, filtered, and concentrated under reduced pressure. The crude mixture was filtered over silica gel using 
petroleum ether and $\mathrm{CH}_{2} \mathrm{Cl}_{2}$, concentrated, and purified by $\mathrm{HPLC}\left(\mathrm{CH}_{3} \mathrm{CN} / \mathrm{H}_{2} \mathrm{O}\right.$ 7:3) and recrystallized from ether/pentane to yield $\mathbf{8 b}$ as orange-yellow crystals $(0.628 \mathrm{~g}, 86 \%$ yield $)$ consisting of a mixture of $Z$ and $E$ isomers (50:50). ${ }^{1} \mathrm{H}$ NMR (300 MHz, [D $\mathrm{D}_{6}$ acetone): $\delta=0.88$ and $0.89\left(\mathrm{t}, J=7.4 \mathrm{~Hz}, 3 \mathrm{H}, \mathrm{CH}_{3}\right), 2.48$ and $2.50\left(\mathrm{q}, J=7.4 \mathrm{~Hz}, 2 \mathrm{H}, \mathrm{CH}_{2}\right), 2.74\left(\mathrm{~s}, 3 \mathrm{H}, \mathrm{CH}_{3}\right)$, 3.78 and 3.79 (t, $\left.J=1.9 \mathrm{~Hz}, 2 \mathrm{H}, \mathrm{C}_{5} \mathrm{H}_{4}\right), 3.93$ and 3.94 (t, J=1.9 Hz, 2H, $\left.\mathrm{C}_{5} \mathrm{H}_{4}\right), 3.99$ (s, 5H, $\mathrm{Cp}), 6.58$ and $6.69\left(\mathrm{~d}, J=8.7 \mathrm{~Hz}, 2 \mathrm{H}, \mathrm{C}_{6} \mathrm{H}_{4}\right), 6.75$ and $6.93\left(\mathrm{~d}, J=8.7 \mathrm{~Hz}, 2 \mathrm{H}, \mathrm{C}_{6} \mathrm{H}_{4}\right), 6.83$ and $7.02\left(\mathrm{~d}, J=8.7 \mathrm{~Hz}, 2 \mathrm{H}, \mathrm{C}_{6} \mathrm{H}_{4}\right), 7.38$ and $7.49\left(\mathrm{~d}, J=8.7 \mathrm{~Hz}, 2 \mathrm{H}, \mathrm{C}_{6} \mathrm{H}_{4}\right), 8.15$ and $8.18(\mathrm{~s}, 1 \mathrm{H}$, $\mathrm{OH}), 8.99$ and 9.03 (s broad, $1 \mathrm{H}, \mathrm{NH}) ;{ }^{13} \mathrm{C} \mathrm{NMR}\left(75.4 \mathrm{MHz},\left[\mathrm{D}_{6}\right.\right.$ ] acetone): $\delta=16.5$ and 16.6 $\left(\mathrm{CH}_{3}\right), 24.9\left(\mathrm{CH}_{3}\right), 29.0$ and $29.1\left(\mathrm{CH}_{2}\right), 69.4\left(2 \mathrm{CH} \mathrm{C} \mathrm{H}_{4}\right), 70.5(5 \mathrm{CH} \mathrm{Cp}), 70.6\left(2 \mathrm{CH} \mathrm{C}_{5} \mathrm{H}_{4}\right)$, 88.3 and $88.4\left(\mathrm{C}_{\mathrm{ip}}\right), 116.5$ and $116.6\left(2 \mathrm{CH} \mathrm{C}_{6} \mathrm{H}_{4}\right), 120.2$ and $120.4\left(2 \mathrm{CH} \mathrm{C}_{6} \mathrm{H}_{4}\right), 131.0$ and $131.5\left(2 \mathrm{CH} \mathrm{C}_{6} \mathrm{H}_{4}\right), 131.9$ and $132.4\left(2 \mathrm{CH} \mathrm{C}_{6} \mathrm{H}_{4}\right), 134.4$ and $137.7(\mathrm{C}), 138.0$ and $138.2(\mathrm{C})$, 139.0 and 139.1 (C), 139.1 and 139.2 (C), 141.5 and 141.8 (C), 157.4 and 157.5 (C), 169.5 (CO); IR (KBr, $\left.\bar{v} \mathrm{~cm}^{-1}\right): 3397(\mathrm{OH}, \mathrm{NH}), 3097,2967,2930,2871\left(\mathrm{CH}_{2}, \mathrm{CH}_{3}\right), 1664$ (CO); MS $\left(\mathrm{CI}, \mathrm{NH}_{3}\right) m / z: 466[\mathrm{M}+\mathrm{H}]^{+}, 483\left[\mathrm{M}+\mathrm{NH}_{4}\right]^{+} ; \mathrm{HRMS}\left(\mathrm{CI}, \mathrm{CH}_{4}, \mathrm{C}_{28} \mathrm{H}_{28} \mathrm{FeNO}_{2}:[\mathrm{M}+\mathrm{H}]^{+}\right)$calcd: 466.1470, found: 466.1453; Anal. calcd for $\mathrm{C}_{28} \mathrm{H} 2{ }_{7} \mathrm{FeNO}_{2} \cdot \mathrm{H}_{2} \mathrm{O}: \mathrm{C}$ 69.57, H 6.05, N 2.90, found: C 69.48, H 5.75, N 2.89 .

\section{MDA-MB-231 cytotoxicity tests}

\section{Materials}

Stock solutions $\left(1 \times 10^{-3} \mathrm{M}\right.$ and $\left.1 \times 10^{-2} \mathrm{M}\right)$ of the compounds to be tested were prepared in DMSO and were kept at $-20^{\circ} \mathrm{C}$. Under these conditions they are stable for at least two weeks. Serial dilutions in DMSO were prepared just prior to use. Dulbecco's modified Eagle's medium (DMEM), fetal calf serum, glutamine, and kanamycin were purchased from Invitrogen (France). Breast cancer cells MDA-MB-231 were from the American Type Culture Collection (ATCC-LGC Standards).

\section{Culture conditions}

Cells were maintained in monolayer culture in DMEM with phenol red/Glutamax ITM supplemented with $9 \%$ of decomplemented fetal bovine serum and $0.9 \%$ kanamycin, at $37^{\circ} \mathrm{C}$ in a $5 \% \mathrm{CO}_{2}$ air-humidified incubator. For proliferation assays, cells were seeded in 24-well sterile plates in $1 \mathrm{~mL}$ of DMEM without phenol red, supplemented with $9 \%$ of decomplemented and hormone-depleted on dextran charcoal fetal bovine serum, $0.9 \%$ 
Glutamax $\mathrm{I}^{\mathrm{TM}}$ and $0.9 \%$ kanamycin. MDA-MB-231 were incubated $24 \mathrm{~h}$ at a density of 20000-30000 cells per $\mathrm{mL}$. The following day (D0), $1 \mathrm{~mL}$ of the same medium containing the compounds to be tested, which were diluted in DMSO, was added to the plates (final volume of DMSO: $0.1 \%$, three wells for each conditions, one plate per day). After $3 \mathrm{~d}$ (D3) the incubation medium was removed and $2 \mathrm{~mL}$ of fresh medium containing the compounds were added. At different days (D3, D4, D5 and D6), the total proteins content of each well were quantified by methylene blue staining as follows: cell monolayers were fixed and stained for 1

$\mathrm{h}$ in $\mathrm{MeOH}$ with methylene blue $\left(2 \mathrm{mg} \mathrm{mL}^{-1}\right)$ and then washed thoroughly with $\mathrm{H}_{2} \mathrm{O}$. $\mathrm{HCl}(2$ $\mathrm{mL}, 0.1 \mathrm{~m}$ ) was then added, and the plate was incubated for $1 \mathrm{~h}$ at $37^{\circ} \mathrm{C}$. Then the absorbance of each well was measured at $\lambda 655 \mathrm{~nm}$ with a Bio-Rad microplate reader. The results are expressed as the percentage of protein versus the DMSO control. Experiments were performed at least in duplicate.

\section{NCI/DTP cytotoxicity and acute toxicity tests}

The protocol for the determination of cytotoxicity on the 60 cell line panel can be found at http://dtp.nci.nih.gov/branches/btb/ivclsp.html; the protocol for acute toxicity testing in mice can be found at http://dtp.nci.nih.gov/branches/btb/acute_tox.html. The DTP homepage can be accessed at http://dtp.cancer.gov/.

\section{Capillary electrophoresis}

All analyses were performed on a Hewlett-Packard ${ }^{3 \mathrm{D}}$ Capillary Electrophoresis system equipped with a diode-array detector. Fused-silica capillaries $(50 \mu \mathrm{m} \mathrm{ID,} \mathrm{total} \mathrm{length} 50 \mathrm{~cm}$, effective length $42 \mathrm{~cm}$ ) were purchased from Polymicro Technologies Inc. (Phoenix, AZ, USA). Before the first use, the capillary was flushed with $1 \mathrm{mM} \mathrm{NaOH}$ solution (HPCE grade, Fluka, Buchs, Switzerland) and $\mathrm{H}_{2} \mathrm{O}$ (HPLC grade, Roth, Karlsruhe, Germany) for 30 min each. Afterward, the capillary was conditioned for $30 \mathrm{~min}$ with the background electrolyte (BGE) $\left(\mathrm{NaH}_{2} \mathrm{PO}_{4}-\mathrm{Na}_{2} \mathrm{HPO}_{4}\right.$ buffer, $50 \mathrm{mM}$, pH 7.4). Before each analysis, the capillary was purged for 1 min with $\mathrm{H}_{2} \mathrm{O}$, for 2 min with $0.1 \mathrm{mM} \mathrm{NaOH}$, and for 2 min with the BGE which was replenished after every third run. The temperature of the capillary as well as of the sample tray was kept constant at $37{ }^{\circ} \mathrm{C}$. Injection was done by applying pressure (10 mbar) for $15 \mathrm{~s}$. Voltage was maintained constant at $15 \mathrm{kV}$. The compound $\mathbf{6 b}(0.5 \mathrm{mM})$ was incubated in $10 \mathrm{~mm} \mathrm{NaH}{ }_{2} \mathrm{PO}_{4}-\mathrm{Na}_{2} \mathrm{HPO}_{4}$ buffer (pH 7.4) with 5'-GMP, 5'-AMP or 5'-CMP to 
obtain molar ratios of 1:2 (complex/nucleotide). The repeated runs were recorded at $\lambda 200 \mathrm{~nm}$ for $10 \mathrm{~h}$. The experiment was repeated three times.

\section{Theoretical calculations}

Theoretical calculations were performed with Titan software [Wavefunction Inc., 18401 Von Karman Avenue, Suite 370, Irvine, CA 92612 (USA)]. A geometry optimization was performed on each molecule to find the absolute energetic minimum using the semi-empirical PM3 Hamiltonian.

\section{Acknowledgements}

We thank P. Herson for crystal structure determination, P. Schluga for nucleotide binding experiments, and the National Cancer Institute Developmental Therapeutics Program for in vitro testing. We thank the Ministère des affaires étrangères for a doctoral fellowship (M.G.), and the Agence Nationale de Recherche for financial assistance ("Mecaferol").

[1] G. Jaouen, Bioorganometallics, Wiley-VCH, Weinheim (Germany), 2006.

[2] G. Jaouen, P. Dyson, in Comprehensive Organometallic Chemistry III, Vol. 12 (Eds.: R. H. Crabtree, D. M. P. Mingos), Elsevier Ltd., Oxford, 2007, pp. 445.

[3] C. G. Hartinger, P. J. Dyson, Chem. Soc. Rev. 2009, 38, 391.

[4] C. S. Allardyce, A. Dorcier, C. Scolaro, P. J. Dyson, Appl. Organomet. Chem. 2005, 19, 1.

[5] T. Gianferrara, I. Bratsos, E. Alessio, Dalton Trans. 2009, 7588.

[6] K. Strohfeldt, M. Tacke, Chem. Soc. Rev. 2008, 37, 1174.

[7] Y. K. Yan, M. Melchart, A. Habtematiam, P. J. Sadler, Chem. Commun. 2005, 4764.

[8] S. Schäfer, I. Ott, R. Gust, W. S. Sheldrick, Eur. J. Inorg. Chem. 2007, 3034. 
[9] M. Melchart, P. J. Sadler, in Bioorganometallics (Ed.: G. Jaouen), Wiley-VCH, 2005, pp. 39.

[10] G. Süss-Fink, Dalton Trans. 2010, 39, 1673.

[11] U. Olszewski, J. Claffey, M. Hogan, M. Tacke, R. Zeillinger, P. Bednarski, G. Hamilton, Invest. New Drugs 2010, DOI: 10.1007/s10637-010-9395-5.

[12] N. Metzler-Nolte, Angew. Chem. 2001, 113, 1072; Angew. Chem. Int. Ed. 2001, 40, 1040 .

[13] S. Top, C. Thibaudeau, A. Vessières, E. Brulé, F. L. Bideau, J.-M. Joerger, M.-A. Plamont, S. Samreth, A. Edgar, J. Marrot, P. Herson, G. Jaouen, Organometallics 2009, 28,1414 .

[14] A. Vessières, S. Top, A. A. Ismail, I. S. Butler, M. Loüer, G. Jaouen, Biochemistry 1988, 27, 6659 .

[15] F. Le Bideau, E. B. Kaloun, P. Haquette, U. Kernbach, J. Marrot, E. Stéphan, S. Top, A. Vessières, G. Jaouen, Chem. Commun. 2000, 211.

[16] A. P. Ferreira, J. L. F. da Silva, M. T. Duarte, M. F. M. da Piedade, M. P. Robalo, S. G. Harjivan, C. Marzano, V. Gandin, M. M. Marques, Organometallics 2009, 28, 5412.

[17] S. Top, A. Vessières, G. Leclercq, J. Quivy, J. Tang, J. Vaissermann, M. Huché, G. Jaouen, Chem. Eur. J. 2003, 9, 5223.

[18] O. Payen, S. Top, A. Vessières, E. Brulé, M. Plamont, M. McGlinchey, H. MullerBunz, G. Jaouen, J. Med. Chem. 2008, 51, 1791.

[19] S. Top, J. Tang, A. Vessières, D. Carrez, C. Provot, G. Jaouen, Chem. Commun. 1996, 955.

[20] S. Top, E. B. Kaloun, A. Vessières, I. Laïos, G. Leclercq, G. Jaouen, J. Organomet. Chem. 2002, 643-644, 350.

[21] A. Vessières, S. Top, W. Beck, E. A. Hillard, G. Jaouen, Dalton Trans. 2006, 529. 
[22] S. Top, A. Vessières, C. Cabestaing, I. Laios, G. Leclercq, C. Provot, G. Jaouen, J. Organomet. Chem. 2001, 637, 500.

[23] P. Pigeon, S. Top, A. Vessières, M. Huché, E. A. Hillard, E. Salomon, G. Jaouen, J. Med. Chem. 2005, 48, 2814.

[24] A. Arezki, E. Brulé, G. Jaouen, Organometallics 2009, 28, 1606.

[25] S. C. B. Gnoatto, A. Dassonville-Klimpt, S. Da Nascimento, P. Galéra, K. Boumediene, G. Gosmann, P. Sonnet, S. Moslemi, Eur. J. Med. Chem. 2008, 43, 1865.

[26] S. Knauer, B. Biersack, M. Zoldakova, K. Effenberger, W. Milius, R. Schobert, AntiCancer Drugs 2009, 20, 676.

[27] B. Long, S. Liang, D. Xin, Y. Yang, J. Xiang, Eur. J. Med. Chem. 2009, 44, 2572.

[28] M. Jung, D. E. Kerr, P. D. Senter, Arch. Pharm. 1997, 330, 173.

[29] M. Schlenk, I. Ott, R. Gust, J. Med. Chem. 2008, 51, 7318.

[30] M. Patra, G. Gasser, A. Pinto, K. Merz, I. Ott, Julia E. Bandow, N. Metzler-Nolte, ChemMedChem 2009, 4, 1930.

[31] A. Houlton, R. Roberts, J. Silver, J. Organomet. Chem. 1991, 418, 107.

[32] C. W. Ong, J. Y. Jeng, S. S. Juang, C. F. Chen, Bioorg. Med. Chem. Lett. 1992, 2, 929.

[33] Y. Yamamoto, K. Yamashita, M. Nakamura, Organometallics 2010, 29, 1472.

[34] M. C. Semenčić, K. Heinze, C. Foerster, V. Rapic, Eur. J. Inorg. Chem. 2010, 1089.

[35] E. Meggers, Chem. Commun. 2009, 1001.

[36] A. Alama, B. Tasso, F. Novelli, F. Sparatore, Drug Discovery Today 2009, 14, 500.

[37] H. Struthers, A. Hagenbach, U. Abram, R. Schibli, Inorg. Chem. 2009, 48, 5154.

[38] L. Wei, J. Babich, W. C. Eckelman, J. Zubieta, Inorg. Chem. 2005, 44, 2198. 
[39] D. Schlawe, A. Majdalani, J. Velcicky, E. Heßler, T. Wieder, A. Prokop, H.-G. Schmalz, Angew. Chem. 2004, 116, 1763; Angew. Chem. Int. Ed. 2004, 43, 1731.

[40] J. C. Franke, M. Plötz, A. Prokop, C. C. Geilen, H.-G. Schmalz, J. Eberle, Biochem. Pharmacol. 2010, 79, 575.

[41] P. James, J. Neudörfl, M. Eissmann, P. Jesse, A. Prokop, H.-G. Schmalz, Org. Lett. 2006, 8, 2763.

[42] Medicinal Organometallic Chemistry, 1st ed., (Eds. G. Jaouen, N. Metzler-Nolte), Springer, Berlin/Heidelberg, 2010.

[43] A. Nguyen, A. Vessières, E. A. Hillard, S. Top, P. Pigeon, G. Jaouen, Chimia 2007, 61, 716.

[44] E. A. Hillard, A. Vessières, L. Thouin, G. Jaouen, C. Amatore, Angew. Chem. 2006, 118, 291; Angew. Chem. Int. Ed. 2006, 45, 285.

[45] P. Pigeon, S. Top, O. Zekri, E. A. Hillard, A. Vessières, M. A. Plamont, O. Buriez, E. Labbe, M. Huché, S. Boutamine, C. Amatore, G. Jaouen, J. Organomet. Chem. 2009, $694,895$.

[46] G. Erker, Macromolecular Symposia 2006, 236, 1.

[47] G. Erker, Polyhedron 2005, 24, 1289.

[48] A. Csámpai, A. Z. Györfi, G. I. Túrós, P. Sohár, J. Organomet. Chem. 2009, 694, 3667.

[49] O. N. Kadkin, H. Han, Y. G. Galyametdinov, J. Organomet. Chem. 2007, 692, 5571.

[50] L. Tebben, M. Neumann, G. Kehr, R. Fröhlich, G. Erker, S. Losi, P. Zanello, Dalton Trans. 2006, 1715.

[51] G. Erker, G. Kehr, R. Fröhlich, J. Organomet. Chem. 2004, 689, 1402.

[52] C. Arisandy, A. R. Cowley, S. Barlow, J. Organomet. Chem. 2004, 689, 775. 
[53] T. J. Brunker, C. Arisandy, A. R. Cowley, L. H. Rees, S. Barlow, D. O'Hare, J. Organomet. Chem. 2004, 689, 252.

[54] P. Liptau, M. Neumann, G. Erker, G. Kehr, R. Frohlich, S. Grimme, Organometallics 2004, 23, 21.

[55] O. Kadkin, C. Näther, W. Friedrichsen, J. Organomet. Chem. 2002, 649, 161.

[56] P. Liptau, S. Knüppel, G. Kehr, O. Kataeva, R. Fröhlich, G. Erker, J. Organomet. Chem. 2001, 637-639, 621.

[57] S.-J. Jong, J.-M. Fang, Org. Lett. 2000, 2, 1947.

[58] R. Sebesta, A. Skvorcová, J. Organomet. Chem. 2009, 694, 1898.

[59] P. Liptau, L. Tebben, G. Kehr, R. Fröhlich, G. Erker, F. Hollmann, B. Rieger, Eur. J. Org. Chem. 2005, 1909.

[60] N. Faux, D. Razafimahefa, S. Picart-Goetgheluck, J. Brocard, Tetrahedron: Asymmetry 2005, 16, 1189.

[61] P. Liptau, D. Carmona, L. A. Oro, F. J. Lahoz, G. Kehr, G. Erker, Eur. J. Inorg. Chem. 2004, 4586.

[62] P. Liptau, L. Tebben, G. Kehr, B. Wibbeling, R. Fröhlich, G. Erker, Eur. J. Inorg. Chem. 2003, 3590.

[63] P. Liptau, T. Seki, G. Kehr, A. Abele, R. Frohlich, G. Erker, S. Grimme, Organometallics 2003, 22, 2226.

[64] L. Tebben, K. Bussmann, M. Hegemann, G. Kehr, R. Froehlich, G. Erker, Organometallics 2008, 27, 4269.

[65] L. Tebben, G. Kehr, R. Fröhlich, G. Erker, Eur. J. Inorg. Chem. 2008, 2654.

[66] D. Plaźuk, A. Vessières, E. A. Hillard, O. Buriez, E. Labbe, P. Pigeon, M. A. Plamont, C. Amatore, J. Zakrzewski, G. Jaouen, J. Med. Chem. 2009, 52, 4964. 
[67] M. Gormen, P. Pigeon, E. A. Hillard, M. A. Plamont, D. Plaźuk, S. Top, A. Vessières, G. Jaouen, Tetrahedron Lett. 2010, 51, 118.

[68] M. Görmen, P. Pigeon, S. Top, A. Vessières, M.-A. Plamont, E. Hillard, G. Jaouen, MedChemComm 2010, 1, 149.

[69] J. E. McMurry, Chem. Rev. 1989, 89, 1513.

[70] CCDC-783005 contains the supplementary crystallographic data (excluding structure factors) for this paper. These data can be obtained free of charge from The Cambridge Crystallographic Data Centre via http://www.ccdc.cam.ac.uk.

[71] Y. L. K. Tan, P. Pigeon, E. A. Hillard, S. Top, M.-A. Plamont, A. Vessières, M. J. McGlinchey, H. Müller-Bunz, G. Jaouen, Dalton Trans. 2009, 10871.

[72] O. Zekri, E. A. Hillard, S. Top, A. Vessières, P. Pigeon, M. A. Plamont, M. Huché, S. Boutamine, M. J. McGlinchey, H. Muller-Bunz, G. Jaouen, Dalton Trans. 2009, 4318.

[73] http://dtp.nci.nih.gov/branches/btb/ivclsp.html (accessed September 19, 2010).

[74] K. D. Paull, R. H. Shoemaker, L. Hodes, A. Monks, D. Scudiero, L. Rubenstein, J. Plowman, M. R. Boyd, J. Natl. Cancer Inst. 1989, 81, 1088.

[75] http://dtp.nci.nih.gov/branches/btb/acute_tox.html (accessed September 19, 2010).

[76] C. G. Hartinger, P. Schluga, M. Galanski, C. Baumgartner, A. R. Timerbaev, B. K. Keppler, Electrophoresis 2003, 24, 2038.

[77] M. Groessl, C. G. Hartinger, P. J. Dyson, B. K. Keppler, J. Inorg. Biochem. 2008, 102, 1060.

[78] A. Dorcier, C. G. Hartinger, R. Scopelliti, R. H. Fish, B. K. Keppler, P. J. Dyson, J. Inorg. Biochem. 2008, 102, 1066.

[79] N. T. Anh, Orbitales Frontières, Manuel Pratique, 2nd edition ed., CNRS éditions and EDP sciences, Paris, 2007.

[80] Z. Zhou, R. G. Parr, J. Am. Chem. Soc. 1990, 112, 5720. 
[81] E. Allard, C. Passirani, E. Garcion, P. Pigeon, A. Vessières, G. Jaouen, J. P. Benoit, J. Controlled Release 2008, 130, 146.

[82] P. W. Fan, J. L. Bolton, Drug Inf. News Drug Metabol. Disp. 2001, 29, 891.

[83] I. Zanellato, J. M. Heldt, A. Vessières, G. Jaouen, D. Osella, Inorg. Chim. Acta 2009, $362,4037$.

[84] E. A. Hillard, P. Pigeon, A. Vessières, C. Amatore, G. Jaouen, Dalton Trans. 2007, 5073.

[85] A. Vessières, S. Top, P. Pigeon, E. A. Hillard, L. Boubeker, D. Spera, G. Jaouen, J. Med. Chem. 2005, 48, 3937.

[86] J. B. Heilmann, E. A. Hillard, M. A. Plamont, P. Pigeon, M. Bolte, G. Jaouen, A. Vessières, J. Organomet. Chem. 2008, 693, 1716. 